${ }^{28}$ The yield of the German corporate income tax is estimated to be 33,4 billion Deutschmarks in 1992, Finanzbericht 1993, 212

${ }^{29}$ See p. 219

${ }^{30}$ See "Current Corporate Income Tax Rates" showing the broad variety of rates on corporate income applie through the Member States from the European Community's Taxation of Corporations, Supplementary Service to European Taxation, Section A, No. 2, Fe bruary 1992 .

${ }^{31}$ See EC Merger Directive of July 23, 1990, EC Coun cil Directive No. 90/434, Official Journal No. 225 of August 20, 1990, p. 1

32 The determination of the profit proceeds on the basis of the commercial balance sheet. Special balance sheet regulations for various forms of corporation must also be considered for tax purposes. The corporation tax law contains provisions to restrict the deductibility of certain operational expenditures such as the capital tax, the turnover tax relating to goods of the corporation which were privately consumed and payments of any kind to members of a supervisory or advisory board.

33 Krause/Laule/Mennel/Mössner/Runge/Viegener Principles of German Tax Law, International Fiscal Association 1981, p. 17 to 23

${ }^{34}$ Reference is made to Attachment 4, "Typical depre ciation rates on industrial buildings and machinery" from the "Ruding Report", p. 179

35 Reference is made to a review of the main tax deductible provisions from the "Ruding Report", p. 247 ; as to this survey, Germany accepts expenditures to build up such provisions if the event occurs durin the business.

36 "Ruding Report", p. 211

37 "Ruding Report" p. 217. As to the international trend, an increasing number of tax systems avoid taxes upon earnings generated through inflation; with res pect to capital gains see Attachment 8 of the "Rudin Report p. 243 and wh respect to inventories see Attachment 9 of the "Ruding Report" p. 181

${ }^{38}$ The "Ruding Report" contains a table on the carry over of trading losses on p. 242 which is attached to this paper as Attachment 6. As to this schedule, international trends indicate an unlimited carry-forward of losses and a carry-back of losses limited timewise. This coordination of the treatment of losses is likely to be introduced by national legislation.

39 "Ruding Report", p. 211

40 "Ruding Report", p. 211, 212

41 "Ruding Report", p. 209

${ }^{42}$ This is the proposal of the "Ruding Report", p. 210 ${ }^{43}$ Reference is made to the "Ruding Report" and there Table 8.8. The table shows the difference between top central-government marginal personal tax rates on earnings and corporate tax rate on retentions.
44 See EC "Parent/Subsidiary" Council Directive No. $90 / 435$, Official Journal No. L 225 of August 20, 1990 p. 6

45 EC Council Convention No. 90/463, EC Official ournal No. L 225 of August 8, 1990, p. 10

Vogel, On Double Taxation Convention, 1991, Art. 25, Note 32: "Only representatives of the authorities of those two states whose taxes are involved may take part in a mutual agreement procedure"; Note 76: "The competent authorities are under no obligation to reach greement in the course of a mutual agreement procedure".

7 EC Official Journal, No. C 53 of February 28, 1991, p. 26

8 Proposal for a Council Directive concerning arranements for the taking into account by enterprises of the losses of their permanent establishments and substiaries situated in other Member States, Official JourNo. C 53 of February 28, 1991, p. 30; Lieb-

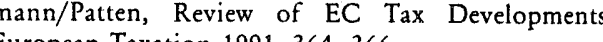
Guropean Taxation 1991, 364, 366

49 This concept was developed on the IFA Congress 1979 at Copenhagen and backed by the resolution. Cf Laule, General Report on: The effect of losses in one country on the income tax treatment in other countries of an enterprise or of associated enterprises engageg in international activites, Cahiers de Droit Fiscal International, LXIVb 1979, p. 71, 94.

\title{
A responsabilidade do transportador aéreo pelo fato do serviço e o Código de Defesa do Consumidor
}

Antinomia entre norma do CDC e de leis especiais

\section{Cláudia Lima Marques}

professora da Universidade Federal do Rio Grande do Sul

e Mestre em Direito pela Universidade de

Tübingen, Alemanha

\author{
Indenizar pela metade é responsabilizar a ví-
} tima pelo resto.

\section{Daniel Pizzaro}

\section{Introdução}

A entrada em vigor de uma nova lei de função social traz como conseqüência natural uma modificação profunda no ordenamento jurídico vigente. ${ }^{2}$

O Código de Defesa do Consumidor é uma destas leis de função social, as quais têm o mérito de positivar as novas noções valorativas orientadoras da sociedade, procurando, assim, assegurar a realização dos modernos direitos fundamentais (direitos econômicos e sociais) previstos nas Constituições. ${ }^{3}$ Leis típicas do intervencionismo do Estado Social, elas nascem com a difícil e específica função de servir de parâmetro de nova orientação, de efetivo instrumento para alcançar o equilíbrio social que o legislador moderno pretende realizar. ${ }^{4}$

Ninguém duvida da árdua e difícil - para muitos praticamente impossível - tarefa de mudar a realidade através de normas jurídicas. ${ }^{5}$ O legislador, porém, na sua sociológica e política finalidade de transformar a realidade cuida de dotar as leis de função social de uma série de características que, no sistema do Direito, isto é, internamente no ordenamento jurídico de determinado país, as possibilitarão cumprir a sua função.

São leis declaradas de ordem pública, a reconhecer a superioridade da lei em rela- ção à autonomia da vontade do indivíduo. São normas, portanto, inderrogáveis pela ação da vontade do indivíduo, a regular de maneira imperativa e imediata as questões jurídicas que tratam. $^{6}$

A modificação no sistema introduzida por estas novas leis é substancial, conseqüência direta do abrangente campo de aplicação que o legislador costuma conceder a estas leis. Muitas vezes, seu campo de aplicação será coincidente com o campo de aplicação de outras leis especiais, de forma a combater privilégios não mais condizen tes com os novos valores que pretende introduzir.

$O$ choque entre as novas leis de função social e as leis anteriores do sistema não pode, portanto, ser evitado, ao contrário, integra a própria finalidade da nova lei, que vem para renovar o sistema e assim transformar a própria realidade social.

A finalidade deste trabalho é, justamente, contribuir ao estudo de um destes conflitos desencadeados pela entrada em vigor no novo Código Consumerista. Trata-se da discussão doutrinária a propósito da aplicação e da compatibilidade das regras sobre a responsabilidade do transportador aéreo previstas na legislação aeronáutica, que limita a responsabilidade e, portanto, a inde- 
nização devida a patamares considerados baixos e o sistema de normas do CDC, que assegura uma indenização efetiva ao consumidor, pelos danos sofridos em virtude de fato do serviço.

Limitar a reparação é, nas palavras fortes de Pizzaro, imputar à vítima, que suporte o resto dos prejuízos não indenizados. ${ }^{8}$ No mundo atual, a tendência é justamente a de socializar os danos, alocar os custos, dividindo-os entre todos na sociedade e não somente sobre os ombros da vítima. A tendência é do ressarcimento amplo, incluindo mesmo os danos extrapatrimoniais, é do ressarcimento efetivo, quando não, ressarcimento integral. ${ }^{9}$

A importância do tema é grande. De um lado, temos o conflito entre uma lei nova de função social e uma lei anterior especial, uma antinomia de princípios, a gerar uma antimonia de normas. De outro, temos o regime de responsabilidade, o qual denot a relevância atribuída, em uma sociedade, proteção dos valores fundamentais, tai como a inviolabilidade da pessoa humana, o direito à vida, à saúde, à segurança, à propriedade e outros direitos fundamentais, mesmo que econômicos ou sociais. Ness sentido, a determinação do atual regime de responsabilidade do transportador aéreo pelo fato do serviço, tenha sido ele modif cado ou não pela entrada em vigor do Có digo de Defesa do Consumidor, passa obrigatoriamente por um exame de sua adequação aos valores estabelecidos na Constituição de 1988, enquanto lei máxima a guiar o sistema de direito brasileiro.

Neste trabalho, limitado por suas próprias características, mais do que repetir as regras da escolástica sobre conflitos de leis no tempo e sobre solução das antinomias em geral, gostaríamos, em uma primeira parte, de concentrar nosso estudo na importância da determinação do campo de aplicação das leis para a solução dos conflitos no tempo e nas dificuldades de estabelecer uma hierarquia entre os critérios clássicos para a solução das antinomias. Na segunda parte, gostaríamos de aprofundar o estudo das regras materiais do regime de responsa134 bilidade previsto tanto na lei antiga, como na lei nova, suas finalidades e suas características principais, de forma a fornecer critérios para a solução, no caso concreto, da antinomia.

I - Repercussão do código de defesa do consumidor na atividade do transporta dor aéreo

O sistema de direito atualmente é formado por um número cada vez maior de miro-sistemas de normas. Fala-se na idade da descodificação, no renascimento do pensamento tópico, no declínio do pensamento sistemático, a resultar em um sistema mais aberto de direito. ${ }^{10}$

Reafirme-se, porém, que o sistema brasileiro de direito, assim como os outros sistemas modernos, deve preservar a sua coerência, a sua visão de todo sistemático, sem perder a capacidade de renovação. Assim, se não é mais o Código Civil sua lei básica, a Constituição representa agora a força guia do sistema. Assim também os micro-sistemas novos devem integrar-se ao todo de forma harmoniosa, sem prejuízo de sua função e de sua força renovadora. Para tanto é necessário que o intérprete solucione as antinomias, os conflitos criados entre normas aparentemente contraditórias presentes em micro-sistemas diferentes. Nesse sentido, o passo número um é esclarecer se os campos de aplicação das normas são coincidentes, ou não haverá contradição possível, pois as leis serão como estradas paralelas, que, num mesmo país, não se encontram jamais.

A repercussão do CDC na atividade do transportador aéreo pressupõe que tal atividade se inclua no campo de aplicação da nova lei, direta ou indiretamente. Mister, portanto, verificar se a nova lei impõe deveres ao transportador aéreo, regula suas obrigações contratuais ou extracontratuais. Note-se que toda vez que se impõe uma obrigação a um agente econômico, estamos imputando a ele uma responsabilidade. São duas visões de um mesmo fenômeno, como um objeto (a obrigação contratual ou extra- contratual), que proteja naturalmente uma sombra (a responsabilidade).

a) Campo de aplicação e conflitos de leis no tempo

Só há conflitos de leis no tempo, se há conflito material entre as leis, ambas considerando-se aplicáveis a uma mesma questão jurídica e impondo regras absolutamente incompatíveis. ${ }^{11}$

Um campo de aplicação coincidente é o início do conflito, pergunta-se o aplicador da lei qual das normas coincidentes deve agora aplicar. ${ }^{12}$

Os conflitos de leis no tempo estão regulados na Lei de Introdução ao Código Civil a qual propõe dois princípios básicos: o da continuidade das leis e da revogação das leis incompatíveis. A revogação expressa, se é a solução mais clara para o conflito, é a mais rara. ${ }^{13} \mathrm{Da}$ mesma forma a revogação tácita propõe sérias dificuldades para o intérprete e nem sempre é possível, tendo em vista a abrangência ou especialidade dos campos de aplicação das normas em conflito. Revogação é a perda da vigência, total ou parcial, da lei e representaria a vontade do legislador, que editou lei posterior incompatível com a anterior. ${ }^{14}$

A expressão conflito de leis no tempo indica, portanto, uma contradição entre normas, mas tende a uma solução definitiva, com a revogação (perda da vigência) de uma das leis ou normas contraditórias. O conflitos de leis no tempo e no espaço são considerados por muitos como as "antinomias por excelência", mas neste trabalho preferimos destacar a expressão "antinomia" como indicando a existência de uma con tradição entre normas, mas propondo uma solução casuística para a contradição sob exame.

As antinomias no direito, para nós, são as contradições aparentes ou reais entre duas normas vigentes e de existência simultânea no mesmo ordenamento jurídico, no momento de sua aplicação a um caso concreto, contradição esta que nega a coerência interna do sistema. A antinomia força o intérprete a compatibilizar os dispositivos legais (possível em caso de antinomias meramente aparentes) ou, não sendo isto possível, leva o aplicador da lei, face ao impasse, a escolher uma, afastando a aplicação da outra (antinomias reais). ${ }^{15}$

A solução da antinomia tem um caráter efêmero, para aquele caso concreto, como todo exercício de interpretação, sem afetar necessariamente, como ocorre nos conflitos, a vigência das normas no sistema. $O$ estudo das antinomias concentra-se, não no problema de vigência das normas novas e anteriores, mas sim no problema de lógica do sistema, influenciando a sua solução, casuísticamente, a eficácia de uma das normas contraditórias. ${ }^{16}$ Os conflitos de leis no tempo e no espaço, se considerados existentes, não afetam a lógica do sistema, pois o próprio sistema positiva as normas pelas quais deseja que se resolvam os conflitos. Eis porque utilizaremos as expressões conflitos de leis e antinomias com significados diferentes, procurando assim compreender a interpretação casuística que a contradição entre o CDC e outras leis especiais desperta.

1. Coincidência entre os campos de aplicaşão da lei nova e das leis anteriores (campo de aplicação "ratione materiae")

A Lei 8.078/90, conhecida como Código de Defesa do Consumidor, nasce como lei especial a tratar das relações de consumo no mercado brasileiro, relações de consumo contratuais e extracontratuais, as quais possuem como elemento caracterizador a presença nos pólos ativo e passivo de um fornecedor e um consumidor ou pessoa a ele equiparada por lei.

Seu abrangente campo de aplicação é determinado pelos artigos $2^{\circ}$, $3^{\circ}$ e 17 , que definem de maneira ampla estes sujeitos de direito: consumidor e fornecedor. A atividade de prestar serviços de transporte, inclusive o transporte aéreo, inclui-se facilmente no campo de aplicação ideal do CDC, uma vez que este corpo de norma pretende aplicar-se a todas as relações, contratuais ou extracontratuais, desenvolvidas no mercado brasileiro, que envolvam um consumidor $e$ um fornecedor, refiram-se a produtos ou 
serviços, excluindo somente os de caráter trabalhista.

O transportador aéreo preenche todas as características exigidas pelo art. $3^{\circ}$ do CDC para definí-lo como fornecedor de serviços. Da mesma forma, a caracterização do passageiro, contratante ou não, como consumdor é determinada ora pela circunstância de ser ele o destinatário final do serviço (art. $2^{\circ}$ CDC), ora pela sua posição como vítima do dano causado pelo fornecimento do serviço (art. $17 \mathrm{CDC}$ ). Por força do art. 17 do $\mathrm{CDC}$, todas as vítimas são equiparadas a consumidores.

$\mathrm{Na}$ atividade do transportador aéreo, porém, incidem normalmente as regras especiais do chamado direito aeronáutico. No que se refere ao tema deste trabalho, observamos que as normas sobre a responsabilidade pelo dano causado à vida ou saúde do passageiro estão previstas tanto no Decreto no 20.704 de 24 de novembro de 1931, que recebeu no ordenamento interno brasileiro a Convenção de Haia de 1929, e sua posterior modificação no Protocolo de Haia, in troduzido pelo Decreto $\mathrm{n}^{\mathrm{0}} 56.463$, de 15 de junho de 1965, para o transporte aéreo de caráter internacional, assim como no atual Código Brasileiro de Aeronáutica, Lei $\mathrm{n}^{\mathrm{O}}$ 7.565, de 19 de dezembro de 1986, para o transporte aéreo nacional.

Estes diplomas tratam de vários aspectos da atividade do transportador aéreo, regulam igualmente o contrato de transporte aéreo e dedicam especial atenção à responsabilidade contratual do transportador, tanto em caso de acidentes aéreos (com danos à saúde), como em caso de má execução contratual (por atraso da prestação e por falha, em caso de perda, danificação ou das bagagens e cargas), positivando normas que permitem a limitação da responsabilidade do transportador. A legislação aeronáutica sobre os acidentes aéreos trata também da responsabilidade decorrente dos danos sofridos por pessoas localizadas na superfície.

Para estabelecer a coincidência de campos de aplicação, no momento, basta afirmar que ambas as leis estabelecem regras sobre a responsabilidade (limitada ou efeti136 va) do transportador frente ao passageiro por danos a sua saúde, segurança e vida causados pela prestação do serviço (fato do serviço). Neste caso, como veremos, há contradição entre o disposto em cada um dos sistemas, um permitindo a limitação da responsabilidade por lei e pelo contrato, enquanto o outro proíbe tal limitação e assegura o direito à efetiva reparação de todos os danos sofridos. Tendo em vista esta contradição aparente, o caso merecerá um exame mais profundo, de forma a podermos concluir pela possibilidade de compatibilizar as normas ou por determinada solução da antinomia.

Em outros pontos, há coincidência no campo de aplicação das mencionadas leis, mas não há contradição entre as normas, como no campo contratual, no que se refere à redação do contrato e ao direito de informação do consumidor-cliente. Sendo assim, as normas do CDC incidem sobre a relação de transporte aéreo entre consumidor e fornecedor, para, por exemplo, impor ao transportador aéreo (ou agência de viagem) o dever de informar (art. 8 a 10 CDC), o dever de dar oportunidade de conhecer previamente o conteúdo do contrato (art. 46 $\mathrm{CDC}$ ), o dever de destacar as cláusulas onerosas para o consumidor (art. $54, \S 4^{\circ} \mathrm{CDC}$, o dever de redação clara e precisa dos contratos de adesão (art. 54, $\S 3^{\circ} \mathrm{CDC}$ ), o dever de identificação, lealdade e não abusividade na publicidade (art. 36 e $37 \mathrm{CDC}$ ), só para citar alguns novos deveres legais pré-contratuais. Nestas matérias, como não há contradição, mas complementação entre os dois diplomas, não há discussão doutrinária sobre a aplicação ou não do CDC, pois se reconhece que o CDC, como lei de função social, foi introduzido para harmonizar e reequilibrar as relações de consumo no mercado, impondo seus novos valores de lealdade e transparência.

2. Abrangência/especializaşão dos campos de aplicaşão e solução dos conflitos de leis no tempo. A revogação (parcial ou total) de uma das leis em conflito no tempo é a solução normal em caso de conflito. A revogação é, porém, a morte da norma jurídica, significa tirar a força obrigatória, a vigência de uma norma, por incompatível com as novas normas impostas pelo legislador. ${ }^{17} \mathrm{O}$ conflito de leis no tempo pode resolver-se pela revogação, se incompatíveis, como dispõe o artigo $2^{\mathbf{o}}$ da Lei de Introdução ao Código Civil, mas a tendência do direito é justamente a contrária, a da continuidade das leis. O exame da compatibilidade das normas deve incluir não só os textos e as finalidades das normas, mas também analisar com cuidado o campo de aplicação de cada norma, pois se os campos de aplicação material e subjetivo são ora coincidentes ora não, não há interesse do sistema na decretação da perda de vigência de uma das nor mas, ao contrário, a sobrevivência de ambas é essencial, ou estaremos criando uma lacuna não querida no ordenamento jurídico.

No caso em exame, mesmo antes de analisarmos a compatibilidade efetiva entre os regimes impostos à responsabilidade do fornecedor pelo fato do serviço, já podemo destacar as dificuldades do aplicador da le em reconhecer a revogação (abrogação ou derrogação) de uma das normas aparentemente em conflito. A dificuldade resiste na abrangência e especialidade diferenciada de seus campos de aplicação.

No campo de aplicação subjetivo, verificamos que o CDC é lei especial, aplicável somente para consumidores em suas relações de consumo (relações com os fornecedores e não com outros consumidores); enquanto as normas contratuais aeronáuticas aplicam-se a todas as pessoas que contratarem com o transportador, sejam consumidores ou outros comerciantes (relações de direito civil ou comercial)

Já no campo de aplicação material, as normas do CDC são ora gerais, ora especiais. São gerais, pois não regulam nenhum contrato em especial, mas especiais, pois regulam somente contratos de consumo, relações contratuais referentes a produtos e serviços. As normas aeronáuticas só se referem a contratos de transporte aéreo, mas também dispõem sobre todas as suas espécies, transporte aéreo de pessoas e de cargas.
Se, na responsabilidade contratual, já enfrentamos dificuldades para afirmar o caráter especial ou não das leis, na responsabilidade extracontratual o quadro é ainda mais nebuloso. $\mathrm{O} C D C$ dispõe novas normas sobre responsabilidade legal, originada por três tipos de contato social: a derivada do fato do produto e do serviço, a derivada da publicidade enganosa ou abusiva, e a derivada do vício do produto ou do serviço, que é imputada também ao fornecedor nãocomerciante, logo sem vínculo contratual com o consumidor.

O regime da responsabilidade pelo fato do serviço, que nos interessa neste trabalho, é amplo. O CDC, pois equipara qualquer vítima do evento a consumidor, o que coadunaria com um regime geral sobre o assunto; mas suas próprias normas limitam ainda mais seu campo de aplicação subjetivo, pois excluem de sua aplicação a relação consumidor-profissional liberal, a qual continua regulada pelo regime comum do Código Civil e leis especiais, se existirem.

Concluindo, existe uma grande dificuldade para caracterizar o CDC, quando em conflito com leis especiais para determinados setores da atividade econômica, como lei especial ou geral. Na verdade, isto é apenas um reflexo do abrangente e multifacetado campo de aplicação desta lei de função social. Assim, no caso em exame, não há dúvidas que os campos de aplicação de ambas as leis tratam da mesma matéria, convergindo para tentar aplicar suas normas ao mesmo caso concreto de responsabilidade por dano causado à saúde ou à vida do passageiro-consumidor.

Há, portanto, coincidência no que tange ao tema de responsabilidade pelo fato do serviço, mas mesmo ai não há coincidência total no campo de aplicação. Como "ratione personae" cada um dos regimes concentra-se na aplicação de suas normas para um determinado sujeito: transportador ou consumidor, há uma especialização-subjetiva multifacetada. Assim, o campo de aplicação subjetivo das normas do direito aeronáutico sobre responsabilidade pelo fato do serviço é mais geral, incluindo os contratos firma- 
dos entre duas pessoas jurídicas, comerciantes, por exemplo, no transporte de carga, contratos comerciais, excluídos da proteção especial do CDC

Ora, se o caráter das normas é ora mais abrangente, ora mais específico, a revogação de uma das normas, o seu desaparecimento no sistema, torna-se impossível, pois criará uma lacuna em todos aqueles temas não tratados pela outra norma. Neste sentido, somente uma lei especial ou geral com campo de aplicação realmente coincidente com a lei especial anterior pode determinar a sua revogação. Se não há revogação, há aplicação simultânea, a nova lei especial, como que roubará a exclusividade do campo de aplicação da outra e forçará sua aplicação conjunta no caso concreto. A solução não é, portanto, a revogação de uma das normas, mas a sobrevivência de ambas no mesmo sistema, para continuarem a atuar no seus campos de aplicação específicos e para atuarem, compatibilizadas, no seu campo coincidente de aplicação. No que se refere ao campo coincidente de aplicação, deverá o intérprete, caso a caso, examinar se há contradição entre as normas e, em existindo a antinomia, decidir, afastando a aplicação de uma das normas no caso concreto.

Assim, se a cláusula de limitação da responsabilidade do transportador está presente em um contrato de consumo, tanto o $\mathrm{CDC}$, como as normas do direito aeronautico encontrarão aplicação. Se o consumidor é pessoa física, estaremos frente a uma antinomia, uma lei permitindo, o que a ou tra proíbe: a limitação através de cláusula contratual do dever de indenizar. Mas se o contrato de transporte aéreo é firmado entre duas pessoas jurídicas, uma como destinatária final do serviço (consumidor) e outra como fornecedora, haverá coincidência no campo de aplicação, mas não contradição entre o disposto nas normas, a antinomia será meramente aparente, pois o próprio CDC, em seu art. 51, I, in fine, permite que "a indenização ... limitada, em situações justificáveis".

Como se observa, a solução não poderia, realmente, ser a da revogação de alguma das 138 normas, eventualmente em conflito no tempo, terá de ser uma solução caso a caso, solução típica das antinomias do sistema. Afirmar simplesmente que o CDC é lei geral e não pode revogar leis especiais anteriores é reduzir-se a uma visão superficial do fenômeno, a qual não ajuda o intérprete, pois no caso concreto ambas as leis, a nova e a anterior, gerais e especiais, encontram aplicação e estabelecem uma antinomia no sistema. Necessário, portanto, analisar os critérios para a solução das antinomias colocados à disposição do aplicador da lei.

b) $A$ solução das antinomias em direito

1. Os critérios para a solução das antinomias e suas dificuldades

A possibilidade de existência de uma contradição entre as normas do mesmo sistema exige do intérprete uma atenção maior para o exame daquelas normas. $O$ intérprete verificará inicialmente se é possível compatibilizar as duas normas pretensamente em contradição. Se uma interpretação compatibilizadora, integrativa, que permita a aplicação das duas normas ao mesmo tempo, é possível, será esta a escolhida e desaparecerá a antinomia meramente aparente.

Se a contradição entre os textos, as normas e suas finalidades é tal que não permite a aplicação conjunta, integradora das normas, uma, por exemplo, permite, enquanto a outra proíbe, uma impõe a renúncia de um direito e a outra proíbe a renúncia do mesmo direito, estamos frente a uma antinomia real, não solucionável através da simples interpretação das normas.

Note-se que a fonte dessa incompatibilidade pode estar no valor que inspirou as leis. Se em um mesmo ordenamento jurídico temos leis inspiradas em valores contrapostos, denomina-se essas antinomias de valores em "antinomias de princípio", as quais determinam, muitas vezes, o nascimento de antinomias reais no sistema. ${ }^{18}$

Em caso de antinomias reais, três são os critérios destacados pela doutrina e utilizados para a jurisprudência para solucionálas: o cronológico, o hierárquico, o da especialização. ${ }^{19}$ Tais critérios podem ser deduzidos das normas positivas sobre a solução de conflitos de leis, mas na verdade sua origem é doutrinária, anterior as próprias codificações e sua idéia de sistema exaustivo.

O critério cronológico é o mais simples para ser determinado, pois depende do momento de entrada em vigor da lei e presume que a lei posterior seja "mais forte" do que a anterior, pois estaria a representar o pensamento e a orientação mais atual do sistema.

Já o critério hierárquico têm sua origem na idéia de hierarquia entre as leis, fixandose hoje, especialmente, no caráter constitucional, complementar ou derivado de uma das normas. No campo interno temos ainda a superioridade reconhecida das normas de ordem pública, pois positivam os valores básicos da sociedade. ${ }^{20}$ Discutiu-se, por muito tempo, se os Tratados (para os monistas) ou os Decretos que os introduzem no ordenamento interno (visão dualista) teriam ou não alguma prevalência ("Vorrang") em relação às leis outras do sistema nacional. Para os internacionalistas a simples origem da norma, no Direito Internacional Público, bastaria para assegurar esta superioridade hierárquica. Hoje reconhece-se que não há superioridade dos Tratados sobre a Constituição $0^{21}$, considerada a lei má xima e basilar do sistema. ${ }^{22}$

Quanto ao conflito entre a lei interna (ordinária) e o Tratado (ou Decreto que o promulga) a discussão continua. A sua beleza está nos sonhos monistas, que negam a existência de dois ordenamentos jurídicos autônomos e independentes, um interno e o outro internacional, preferindo ver o mundo como um só sistema, com o recebimento automático dos Tratados assinados pelo país. ${ }^{23}$

Mesmo sendo o Brasil por tradição um Estado dualista ${ }^{24}$, não se pode esquecer que o monismo tem como base última a doutrina jusnaturalista, que confunde o Direito Internacional Público com o próprio Direito Natural; nesse sentido as normas oriundas deste direito supranacional trariam em si uma justiça intrínseca, a ratio naturalis universal.
Sobre o tema, DE VISSCHER identificou três tipos de sistemas constitucionais: os que reconhecem ao Tratado, depois de inserido na ordem interna, a mesma autoridade que a lei, sem superioridade ("no supperior efficacy"), como o sistema norte-americano; os sistemas que reconhecem a superioridade do Tratado frente a lei, mas submetem o conflito a um controle constitucional, como o sistema alemão e de outros países hoje pertencentes à Comunidade Econômica Européia; e por fim os que eventualmente estabelecessem a superioridade do Tratado sobre a lei, sem controle da constitucionalidade, sistema que seria baseado em um monismo radical, de superioridade do Tratado sobre a própria Constituição nacional, previsto, segundo o Autor, nos Paises-Baixos. ${ }^{25}$

No Brasil, o Supremo Tribunal Federal, ainda sob a égide da Constituição de 69, afirmou no RE 0109173/87, ser "Inadmissível a prevalência de Tratados e Convenções Internacionais contra o texto expresso da Lei Magna." Se a Constituição é superior, são suas normas que estabelecem a hierarquia no sistema e não há norma constitucional que estabeleça a superioridade dos Decretos, que recebem Tratados.

Como ensina REZEK $^{26}$, a Constituição Federal de 1988 não prestou maiores homenagens ao Direito Internacional Público a não ser àquelas que ele realmente merece, isto porque as regras do cenário internacional não estão totalmente fixadas e dependem ainda muito do poder econômico e da importância política de cada país; assim, não é pelo simples fato de ter sido uma norma inserida em um ato internacional que assegura a ela o fato de ser uma norma justa ou que sua aplicação seja para sempre conveniente para o Brasil. ${ }^{27}$ Ainda é necessário diferenciar entre as normas oriundas da ordem internacional e recebidas no ordenamento jurídico brasileiro. Há aquelas que positivam valores internacionais, como as que dispõem sobre os direitos humanos e garantias fundamentais, mencionados no parágrafo segundo do art. $5^{\circ} \mathrm{da}$ Constituição e há aquelas que tratam de interesses 
econômicos internacionais (Tratados sobre a dívida externa, sobre o direito do mar direito aeronáutico, direito espacial etc.)

Com base no dualismo brasileiro e na superioridade assegurada tradicionalmente à Constituição, a doutrina ${ }^{28}$ e a jurisprudência atual tem negado a existência de uma superioridade hierárquica entre o Tratado recebido no ordenamento jurídico interno e a legislação outra interna, principalmente em matéria tributária e comercial. ${ }^{29}$

Já o critério da especialização baseia-s na idéia de leis especiais para reger determinados assuntos ou determinadas pessoas leis gerais, pressupondo a maior força das leis específicas. ${ }^{30}$

Também o critério da especialização evoluiu no tempo e relativou-se. Hoje reconhece-se que a especialização é uma característica tanto material como subjetiva, pois cada vez mais se introduz no sistema de direito leis destinadas à proteção de grupos sociais. ${ }^{31}$

Com as modificações sofridas pela ciência do direito neste século, há um crescent ceticismo quanto a possibilidade dos critérios tradicionais, propostos desde a escolástica, fornecerem soluções absolutas. No campo do Direito intertemporal, reconheceu-se, na França, ${ }^{32}$ que as soluções propostas par o problema da retroatividade da lei e do respeito ao direito adquirido não resultam de uma análise meramente jurídica, são con junturais, dependendo de fatores filosóficos sociológicos e ideológicos, o que impede caráter absoluto das soluções encontradas.

Assim, por exemplo, a concepção filosófica que o aplicador da lei tenha sobre o direito pode influenciar a sua decisão, poi os efeitos retroativos da lei social nova serão visualizados de forma diferente por aqueles de filosofia mais individualista por aqueles que concedem maior importância ao bem comum da sociedade como um todo. Da mesma maneira, a sucessão de lei no tempo possui uma inseparável dimensão sociológica, bastando lembrar que algumas leis são modificadas pelo legislador para que a previsão legal se harmonize com a moral e os costumes atuais (um exemplo, 140 seria a figura introduzida pela nossa Constituição em 1988 da união estável), e sua aplicação imediata não refletirá em excesso na sociedade, já outras leis estão "a frente" da prática social, pois o legislador deseja justamente transformar, orientar a nova conduta que a sociedade terá de assumir, aqui a vacatio legis será maior e a aplicação será imediata, mas para o futuro, pedagógica e moderada. Por fim, a ideologia do legislador pode influenciar a solução. O legislador de inspiração conservadora adota sistemas que permitam preservar a estabilidade dos direitos adquiridos, dos atos jurídicos perfeitos, enquanto o legislador manifestamente reformista é mais sensível a necessidade de colocar imediatamente em prática as novas normas, as quais considera mais equitativas que as anteriores. ${ }^{33}$

Esta relativização ocorrida na França, serve-nos para introduzir a dificuldade maior em matéria de antinomia, que é a hierarquia entre os próprios critérios.

2. Conflito de critérios e insuficiência dos critérios

Se dois critérios, aplicados ao mesmo conflito de normas, propõem soluções diferentes, estamos frente a um conflito de critérios. Assim, se o CDC, considerado como lei geral posterior, é hierarquicamente superior a uma lei anterior, considerada lei especial, como decidir? Prevalecerá o critério da especialização ou o hierárquico?

Para BOBBIO, se o conflito é entre o critério cronológico e o hierárquico, prevalecerá o hierárquico claramente; mas se o conflito é entre o cronológico e o da especialização, a resposta já não é tão simples. A jurisprudência costuma presumir que prevalecerá o critério da especialização (lex posterior generalis non derogat priori speciali). Assim, o conflito entre uma lei geral-posterior e uma lei especial-anterior seria resolvido pela presunção que o legislador sabia do regime especial e não quis afastá-lo pela nova lei geral, pois o regime especial propriciaria maior justiça do que o geral. Trata-se, porém, de uma presunção, arraigada, sem dúvida, ao espírito dos juristas, mas que, segundo o autor não é absoluta, pois a nova lei geral pode muito bem quere modificar o sistema, passar do privilégio à abolição deste privilégio para a maior justição social, prevalecendo sua aplicação por uma questão teleológica. ${ }^{34}$

Em caso de conflito entre as soluções propostas pelo critério hierárquico e o da especialização, prevale o critério hierárquico sobre o da especialização. Neste caso também, certas relativizações são necessárias. A jurisprudência tende a conceder prevalência às normas especiais, sempre que não em contradição com a Constituição que o regime particular realmente se justifique, não constituindo mero privilégio. ${ }^{35}$

A hierarquia entre os critérios, portanto, não é tão clara e baseia-se em presunções não absolutas a exigir um esforço casuístico do intérprete. Cabe ainda mencionar que se ambas as normas são do mesmo nível (normas de ordem pública, por exemplo), amba gerais ou especiais e contemporâneas, não há solução possível usando-se somente os três critérios, logo o intérprete deverá reco rer a uma terceira fonte, a Constituição, po exemplo, e solucionará a antinomia através do sistema, seus valores constitucionais sua razoabilidade.

Cada vez mais, em se tratando de conflitos entre critérios se utiliza uma interpretação "conforme a constituição" para destaca a norma que deverá efetivamente ser aplicada ao caso concreto, afastando a outra solucionando a antinomia entre as normas.

II - O atual regime da responsabilidade pelo fato do serviço

Enquanto a expressão "fato do produto" encontra entre nós certa receptividade ${ }^{36}$, querendo significar os danos à saúde e à segurança originados do contato entre uma ou mais pessoas e um produto, industrializado ou não, no mercado de consumo, a expressão "fato do serviço" foi introduzida somente em 1990 pelo Código de Defesa do Consumidor (Lei 8.078/90), a positivar a relevância dos efeitos sociais da relação de consumo no mercado, envolva ela em sua origem a atividade do fornecedor de colocar a disposição no mercado produtos ou serviços. ${ }^{37}$ A responsabilidade pelo fato do serviço situa-se, se assim podemos ainda afirmar, no campo da responsabilidade extracontratual, tanto que o artigo 17 do CDC equipara todas as vítimas do evento causado pelo produto ou pelo serviço a consumidores.

A expressão "fato do serviço" foi incluída no título da Seção II do capítulo IV do CDC, dedicado à prevenção e à reparação dos danos, querendo significar o evento danoso oriundo do contato entre uma ou mais pessoas e um serviço defeituoso prestado pelo fornecedor no mercado. A doutrina tradicional preferia a expressão "responsabilidade civil" ou "aquiliana" do prestador de serviços para significar o mesmo fenômeno. Feitas estas observações terminológicas, gostaríamos, de traçar um painel, ainda que geral, da responsabilidade ilimitada pelo fato do serviço imputada pelo novo Código e da responsabilidade limitada pelo dano à saúde dos passageiros imputada ao transportador aéreo pelas normas da Convenção de Varsóvia e do Código Brasileiro de Aero. náutica. $O$ objetivo desta nossa análise verificar a finalidade de cada regime, a hierarquia e a especialidade de suas normas, assim como as características materiais de cada micro-sistema, de forma a poder estabelecer a eventual contradição entre eles fornecer instrumentos para que o intérprete possa solucionar esta antinomia em nosso sistema de direito.

a) $A$ responsabilidade pelo dano à saúde no transporte aéreo segundo a Convenşão de Var sóvia e o Código Brasileiro de Aeronáutica

Apesar da semelhança dos contratos de Ansere por via terrestre, lacustre ou marítima e do contrato de transporte via aérea, submetem-se eles a regimes jurídicos diferentes. No Brasil, o regime destes contratos encontra-se regulado em alguns aspectos es peciais por normas da Convenção de Varsóvia e do Código Brasileiro de Aeronáutica que serão objeto de nossa análise, tanto da sua finalidade, quanto das características da 
responsabilidade do transportador aéreo assegurada nestas normas.

Dụas são as fontes onde podemos encon trar normas específicas sobre a responsabilidade do transportador por danos à saúde, à segurança do transportado ou de terceiro: - Decreto que promulgou a Convenção de Varsóvia de 1929 e suas modificações e Código Brasileiro Aeronáutico (CoBA)

A legislação sobre os acidentes aéreos tra ta tanto da responsabilidade pelos dano sofridos pelos passageiros, quanto da responsabilidade decorrente dos danos sofridos por pessoas localizadas na superfície em nossa análise vamos nos concentrar na primeira hipótese, pois mais próxima idéia de relação de consumo, se bem que a definição equiparada das vítimas a consumidores pelo art. 17 CDC possa vir a englobar todo o conjunto de situações.

A Convenção de Varsóvia, de 12 de outubro de 1929, foi recebida no ordenamento jurídico interno brasileiro através do Decreto n. 20.704 de 24 de novembro de 1931 , assim como sua posterior modificação no Protocolo de Haia, introduzido pelo Decreto n. 56.463 , de 15 de junho de 1965 , passando a regular o transporte aéreo de caráter internacional. ${ }^{38}$ Regras especiais sobre a responsabilidade no transporte aéreo interno foram introduzidas pelo antigo Código Brasileiro do Ar, Decreto 483, de 8 de junho de 1938, pelo segundo Código Brasileiro do Ar, Decreto 32, de 18 de novembro de 1966 e suas modificações e pelo atual Código Brasileiro de Aeronáutica, Lei 7.565, de 19 de dezembro de 1986, ainda em vigor.

\section{Características}

Afirma Octanny Silveira DA MOTA ${ }^{39}$, a existência, no ordenamento jurídico brasileiro, de um microsistema de normas aero náuticas; legislação esta que somente disciplina determinadas questões específicas ligadas ao transporte aeronáutico ${ }^{40}$, tendo, porém, naquilo que trata a força e o efeito típico da lei especial para a matéria tratada. Mister, portanto, que se examine com mais atenção as normas especiais sobre a responsabilidade do transportador aéreo. a) Finalidade e bierarquia das normas

Como ensina Antônio Chaves ${ }^{41}$, para se compreender a matéria é preciso remontar ao início deste século, quando a aviação ainda era uma atividade em nascimento e onde os riscos eram enormes tanto para os passageiros ${ }^{42}$, para a carga transportada, para os tripulantes e para a própria empresa aérea. A aplicação das regras da responsabilidade comum dificultavam o desenvolvimento deste importante setor econômico e ao mesmo tempo permitiam que se incluísse, na maioria dos contratos de transporte oferecidos pelas empresas, cláusulas de exoneração da responsabilidade ${ }^{43}$. Da aplicação das normas de direito comum resultaria, de qualquer maneira, a necessidade do transportado-vítima do acidente de consumo provar a culpa ${ }^{44}$ do transportador aéreo para obter o ressarcimento de seus danos.

Tendo em vista esta situação, de um lado a presença de cláusulas de não-indenizar e de outro o risco da decretação de indenizações ilimitadas para todas as vítimas, elaborou-se, de 1925 a 1929, a Convenção de Varsóvia, a qual, de um lado, proibiu a utilização de cláusulas de não-indenizar ou de cláusulas que estabelecessem indenizações inferiores ao estabelecido na Convenção e estabeleceu uma presunção juris tantum de responsabilidade do transportador pelos prejuízos decorrentes do transporte, mas, de outro, estabeleceu um limite para a responsabilidade do transportador, limite este só excepcionalmente ultrapassado. ${ }^{45}$

Segundo ensina Antônio CHAVES, duas foram as preocupações principais da Convenção de Varsóvia (Dec, 20.704/31 e Dec. $56.463 / 65$ ): de uma lado estabelecer o equilíbrio entre as posições do usuário e do transportador e de outro estabelecer uma disciplina internacional uniforme, ou universal, para o transporte aéreo, ${ }^{46}$

Já para o mestre de Pádua, Tito BALLARINO $^{47}$, a limitação da responsabilidade do transportador aéreo na Convenção de Varsóvia teria uma única finalidade: conseguir uma repartição do risco entre a coletividade dos passageiros, que renunciavam a uma reparação integral, mas que tinham a vanta- em de pagar um bilhete de avião menos caro, do que se o transportador aéreo tivesse de fazer face a indenizações ilimitadas. A argumentação de BALLARINO é reforçada pela doutrina aeronáutica tradicional, que vê a especialidade do regime da responsabilidade do transportador aéreo baseada justamente na renúncia (ou, se preferirem, no consentimento com a atividade de risco) por parte dos passageiros às normas ordinárias de responsabilidade. ${ }^{48}$

Quanto à hierarquia destas normas, especialmente das normas oriundas de Tratado internacional recebidas no ordenamento jurídico interno, utiliza-se com freqüência argumento da universalidade das normas da obrigação internacional do Estado Brasileiro de cumprir normas até a denúncia do Tratado, corroborando com a tese da superioridade destas normas "internacionais" sobre as outras normas internas, o que levaria a impossibilidade de uma lei posterior derrogar ou afastar a norma "internacional".

No caso da Convenção de Varsóvia foi ela recebida de maneira perfeita no ordenamento jurídico interno brasileiro, e até hoje não foi denunciada pelo Executivo. Mas aceitaria o sistema brasileiro a superioridade das leis oriundas de Tratados internacionais? Como já analisamos anteriormente, tal hierarquia diferenciada entre a lei que introduz Tratado na ordem interna e as outras leis internas não encontra base no sistema constitucional brasileiro. Quanto a universalidade ou internacionalidade da norma outras dúvidas aparecem. Seria realmente a cláusula de limitação de responsabilidade do transportador aéreo, nestes patamares hoje considerados tão baixos, uma universalidade? Fixaria a Convenção de Varsóvia sempre o mesmo limite, não importando o porto de partida, de destino ou a nacionalidade da vítima? E mais ainda seria o fato das cláusulas presentes nos contratos aéreos encontrarem utilização em vários países juridicamente suficiente para afastar delas o controle judicial ordenado pela lei intern posterior? A análise da responsabilidade prevista no sistema de Varsóvia e o estudo da chama- da "crise da Convenção de Varsóvia" poderão ajudar-nos a responder estas questões.

b) Natureza subjetiva, inversão do ônus da prova e elementos da responsabilidade

A responsabilidade do transportador aéreo prevista na Convenção de Varsóvia é uma responsabilidade subjetiva, baseada na culpa. O sistema básico da Convenção representa-se por duas normas: a) a da presunção de culpa do transportador aéreo (ônus), tanto em caso de morte, de ferimento ou de outra lesão corporal sofrida pelo viajante, como em caso de perda, destruição ou avaria das bagagens registradas e cargas; com a inversão do ônus da prova, o passageiro não precisa provar a culpa do transportador, basta a simples existência do dano, mas a inexistência de culpa pode levar a desoneração do transportador, e b) a da limitação da responsabilidade do transportador. ${ }^{49}$

Segundo dispõe o art. 17 da Convenção de Varsóvia, o transportador responde pelo dano ocasionado por morte, ferimento ou qualquer outra lesão corpórea sofrida pelo viajante, desde que o acidente, que causou o dano, haja ocorrido a bordo da aeronave, ou no curso de quaisquer operações de embarque ou desembarque. Segundo dispõem os artsı 20 e 21 , o transportador não será responsável se provar "que tomou, e tomaram os seus prepostos, todas as medidas necessárias para que se não produzisse o dano, ou que lhes não foi possível tomálas", ou poderá ver excluída ou atenuada a sua responsabilidade se provar "que o dano foi causado por culpa da pessoa lesada, ou que esta para ele contribuiu". A responsabilidade fica presumida, sob prova em contrário, mas ficaria excluída se provada a ocorrência de força maior ou caso fortuito, bem como, a culpa exclusiva da vítima.

A norma que prevê a limitação da responsabilidade é aquela do art. 22. Segundo o texto do art. 22 da Convenção de Varsóvia, modificado pelo Protocolo de Haia de 1955, "no transporte de pessoas, limita-se a responsabilidade do transportador à importância de 250.000,00 (duzentos e cinqüenta mil) francos poincaré". "Se a indenização, 
de conformidade com a lei do tribunal que conhecer a questão, puder ser arbitrada em constituição de renda, não poderá o respectivo capital exceder aquele limite", sendo que no limite não se incluem as despesas para ressarcir os custos judiciais e os honorários advocatícios.

Trata-se, portanto, de uma responsabilidade limitada (begrenzte Haftung), cujo montante poderá variar conforme o dano sofrido, não podendo porém superar o limite fixado.

Este limite sofre duas exceções: 1) segundo dispõe o art. 22, $3^{\mathbf{a}}$ parte, um limite maior de responsabilidade pode ser fixado por acordo entre o transportador e o usuário; 2) segundo dispõe o art. 25 , modificado pelo Protocolo de Haia, o transportador não poderá se prevaler do limite previsto no art. 22, em caso de dolo ou culpa grave sua, ou de seus prepostos. ${ }^{5}$

A última norma a ser mencionada é a do art. 23 da Convenção, segundo a qual será nula e de nenhum efeito toda e qualquer cláusula tendente a exonerar o transportador de sua responsabilidade, ou estabelecer limite inferior ao que lhe fixa a Convenção, mas a nulidade da cláusula não acarretara a do contrato.

Concluindo, trata-se, no sistema da Convenção de Varsóvia, da imposição de uma responsabilidade subjetiva, e não objetiva, como afirmam alguns, baseada na presunção de culpa juris tantum, que inverte o ônus da prova a favor do consumidor, mas que limita a responsabilidade total do transportador a patamares que, como veremos, são considerados baixos.

Quanto a natureza do limite, cabe distinguir a responsabilidade tarifada da responsabilidade limitada. Na tarifação se presume o dano (evento morte, perda de um braço, de uma capacidade laborativa etc.) e se quantifica estes tipos de danos, na limitação não se presume o dano, este tem que ser provado, o limite opera somente como um quantum máximo, logo, se o dano comprovado for de menor valor, a indenização poderá ser fixada abaixo do limite máximo. ${ }^{52}$ No caso do sistema da Convenção de Varsóvia, o limite previsto no art. 22 é um 144 limite máximo, que não leva a presunção do dano, logo, estamos frente a uma responsabilidade limitada. Note-se, porém, que a Convenção não menciona, e portanto não impede que se fixe, através de previsão no contrato ou em sentença judicial, valores inferiores ao limite máximo previsto.

Por sua vez, o Código Brasileiro de Aeronáutica (CoBA), lei 7.565 , de 19 de dezembro de 1986, trata de diversos assuntos relacionados ao transporte e as empresas nele envolvidas, tratando igualmente do contrato de transporte aéreo a partir de seu artigo 222. A responsabilidade contratual do transportador mereceu especial destaque, $e$ foi ela limitada, segundo dispõe o art. 246 , aos limites estabelecidos nos artigos 257,260,269 e 277 do Código.

Segundo dispõe o art. 257 do CoBA, "a responsabilidade do transportador, em relação a cada passageiro e tripulante, limita-se, no caso de morte ou lesão, ao valor correspondente na data do pagamento, a 3.500 (três mil e quinhentas) Obrigações do Tesouro Nacional - OTN..." esclarecendo o seu $\S 1^{\circ}$ que poderá ser fixado limite maior mediante pacto acessório entre o transportador e o passageiro.

De maneira surpreendentemente e original o CoBA afirma (a contrário) o caráter supletivo destas normas, dispondo no art. 251 que "na fixação da responsabilidade do transportador por danos a pessoas... a bordo da aeronave aplicam-se os limites dos dispositivos deste Capítulo, caso não existam no contrato outras limitações. "Isto é, permitindo que se estipulem nos contratos de transporte aéreo, valores indenizatórios ainda in feriores aos previstos em lei.

Já o art. 248 do CoBA parece querer seguir o exemplo da Convenção de Varsóvia, que "os limites de indenização, previstos neste Capítulo, não se aplicam se for provado que o dano resultou de dolo ou culpa grave do transportador ou de seus prepostos."

c) Valor da Indenização Limitada

A determinação do valor exato da indenização fixada pela Convenção de Varsóvia não é fácil, como bem demonstra a decisão do Supremo Tribunal Federal no RE 113.498-4, em $1987,{ }^{53}$ onde conclui que mesmo o Banco do Brasil teria se enganado. Razão para toda esta insegurança é que o franco poincaré em verdade não existe mais, pois a paridade do franco com o ouro foi extinta ${ }^{54}$, assim como aconteceu com muitas outras moedas. A partir dai surgem soluções contraditórias, umas preconizando o uso do valor em ouro previsto no Protocolo de Haia (cada unidade monetária constituída de 65,5 miligramas de ouro, ao título de 900 milésimos de metal fino), ${ }^{55}$ calculado pelo valor do ouro ao dia da sentença de liquidação ${ }^{56}$; outras tomam por base o valor do franco-ouro estimado pelo Banco do Brasil em cruzeiros, ou mesmo a onsa-troy fixada em dólares pelo governo dos Estados Unidos. ${ }^{57}$

Sem querer participar desta discussão, considero que bastaria afirmar que os $250.000,00$ francos-poincaré previstos no Protocolo de Haia equivaliam a 16.600 dólares americanos ${ }^{58}$, o que representa mais ou menos o preço de 5 passagens aéreas para a Europa, como limite máximo para a indenização (inclusive a devida em prestações alimentícias mensais) por morte, por exemplo, do executivo, pai da família.

Como ensina AGUIAR DIAS sobre a cláusula limitativa de responsabilidade: "Sem embargo de sua utilidade, pois estimula os negócios, mediante o afastamento da incerteza sobre o quantum da reparação, a cláusula limitativa muitas vezes resulta em burla para o credor. Dificilmente se dá o caso de ser o dano real equivalente à reparação prefixada: o mais freqüente é representar um simulacro de perdas e danos." $\mathrm{O}$ mestre brasileiro da Responsabilidade $\mathrm{Ci}$ vil, muito antes de pensarmos na defesa do consumidor, sustentava a nulidade dest cláusula, "quando a soma arbitrariamente fixada resulte em verdadeira lesão para o credor, principalmente quando se trate de transporte, cujo contrato geralmente é de natureza a excluir a liberdade de discussão por parte do interessado no serviço". ${ }^{60}$

Podemos, neste caso, concluir que se a intenção da Convenção de Varsóvia era realmente estabelecer o equilíbrio entre as po- sições do transportador e do usuário do transporte aéreo, este equilíbrio não foi atingido com a simples inversão do ônus da prova e com a manutenção do princípio da culpa, pois o limite da responsabilidade foi fixado em patamar realmente tímido, a limitar a ação da justiça. Sob o ponto de vista da responsabilidade civil a vantagem trazida pela Convenção é maior para o transportador aéreo, que se é obrigado a fazer um seguro pode conhecer antecipadamente a extensão dos montantes de indenização, o que diminui seus custos, ainda mais hoje quando o transporte aéreo já provou ser um dos mais seguros estatisticamente. ${ }^{61}$

Quanto ao Código Brasileiro de Aeronáutica, tendo em vista a dificuldade criada com a extinção dos índices por ele utilizados para fixar o montante das indenizações, fica praticamente impossível, neste rápido estudo, informar o valor exato da indenização por morte, em se tratando de transporte aéreo nacional. Da jurisprudência consultada, porém, duas conclusões podem ser retiradas. A primeira é que o valor fixado pelo CoBA é inferior ao fixado pela Convenção de Varsóvia, assim como era o valor fixado pelo antigo Código Brasileiro do $\mathrm{Ar}^{62} \mathrm{Em}$ segundo lugar, que a insuficiência $\mathrm{da}$ indenização leva a jurisprudência $\mathrm{a}$ interpretar (assim como faziam os norte-americanos antes do Acordo de Montreal) de maneira bastante ampla o conceito de culpa grave e de dolo aéreo, ajudados pela Súmula 229 do Supremo Tribunal Federal, de forma a afastar a limitação indenizatória e possibilitar o ressarcimento pelo Direito Comum. ${ }^{63}$ Por fim, cabe mencionar que o Dec.-lei 32/66, em seu art. 150 , regularia a decadência do direito de indenização, fixando o prazo em dois anos.

2. Crise do sistema da Convenção de Varsóvia e seus reflexos na limitação da responsabilidade do transportador aéreo.

Como noticiava GAJA ${ }^{64}$, os limites fixados em Varsóvia e aumentados em Haia, em 1955 sempre foram motivo de muita polêmica no mundo inteiro. Com o tempo e com a desvalorização do ouro e das moedas, 
o montante no qual a responsabilidade do transportador estava limitado tornou-se muito baixo, de maneira que os passageiros, especialmente em caso de acidente fatal, passaram a suportar, eles, um risco muito grande, assim, de maneira diferente, a jurisprudência de vários países têm se esforçado para amenizar as conseqüências inequitativas desta alocação de riscos. Fala-se assim em uma crise do sistema de Varsóvia. ${ }^{65}$

a) $A$ reação nos Estados Unidos e o fim da universalidade

Em 15 de novembro de 1965, os Estado Unidos pressionados por importante parte da opinião pública, que considerava que a aviação internacional não necessitava de proteção especial em relação à proteção merecida pelas vítimas, por associações de juristas, e por decisões jurisprudenciais da última década, apresentaram a notificação de sua denúncia à Convenção de Varsóvia ${ }^{66}$ Sob tal ameaça e tendo em vista que em se tratando de transporte aéreo nenhum país no mundo é tão importante como os Estados Unidos da América, as normas da Convenção de Varsóvia começaram a relativizar-se.

Os Estados Unidos deixaram claro que os motivos, que o levaram a denúncia do Tratado, eram os baixos limites da responsabilidade por morte ou dano pessoal pessoa previstos na Convenção e mesmo no Protocolo de $\mathrm{Haia}^{67}$ e só voltaram atrás, retirando a denúncia seis meses após, quando obtiveram a promessa que a Convenção seria radicalmente mudada. ${ }^{68}$

Acontece então a Convenção de Montreal, com a presença de 98 países, e os Estados Unidos propõe que se aumente o limite para o valor de 100.000 U\$ (cem mil dólares americanos) para o caso de morte, argumentando que o aumento dos custos de seguro seriam insignificantes. A França, a Polônia e alguns países latino-americanos propõem que se aumente somente até 50.000 U\$ (cinqüenta mil dólares americanos), outros propõem que se chegue a 75.000 U\$ (setenta e cinco mil dólares americanos), como a Suécia, Alemanha e Nova Zelândia. ${ }^{69}$ Face a impossibilidade de um acordo definitivo, pois simplesmente o consenso não aconteceu, optou-se por elaborar um interim arrangement ${ }^{70}$ somente com os Estados Unidos.

De acordo com o Arrangement de Montreal dos Estados Unidos com as companhias aéreas filiadas a CAB e a IATA ${ }^{71}$, um total de 80 companhias aéreas comprometeram-se a aumentar os limites da responsabilidade para vôos partindo, chegando ou com escalas nos Estados Unidos, para 75.000 U\$ (setenta e cinco mil dólares americanos) e note-se, uma responsabilidade absoluta, não baseada na culpa. ${ }^{72}$ Teoricamente 0 acordo interino de Montreal não anulou ou denunciou a Convenção de Varsóvia, pois o art. 22, permitia que os limites previstos na Convenção fossem aumentados por acordo com os usuários. Ora, como são as companhias que redigem os contratos, sem discussão com os consumidores, passaram elas a incluir para os vôos tocando o solo norteamericano uma folha a mais em seu bilhete de passagem, contendo as novas regras. ${ }^{73}$

O sistema de Varsóvia não conta, portanto, mais com sua universalidade. ${ }^{74}$ Mas teria o fato da norma que permite a limitação da responsabilidade ter sua origem em um acordo de Direito Internacional Público paralizado a força interpretativa dos judiciários nacionais? Seria a ameaça de denúncia da Convenção a única forma de proteger os seus cidadãos contra limites reduzidos para a responsabilidade civil? Note-se que nos Estados Unidos, mesmo após o acordó de Montreal, o limite da responsabilidade do transportador aéreo foi novamente atingido pela decisão de 17 de abril de 1984, Trans World Airlines Inc. v. Franklin Mint Corp. 82 USC 1186(1984), por problemas de conformidade do limite com a Constituição Federal norte-americana. ${ }^{75} \mathrm{~A}$ crise do sistema $\mathrm{d}$ Convenção de Varsóvia seria sentida também na Itália.

b) A reaşão na Itália e o Problema da Constitucionalidade da Convenção de Varsóvia Desde 1978, a jurisprudência e os doutrinadores italianos manifestaram dúvidas sobre a constitucionalidade da lei interna, que, recebendo a norma da Convenção de Varsóvia, limitava a responsabilidade do transportador aéreo em caso de morte ou de dano à saúde ou à segurança a patamares considerados baixos. ${ }^{76}$

A doutrina acabou concluindo que, quando a limitação de responsabilidade permitida por uma lei interna é tal de forma a verdadeiramente privar a vítima de um direito de efetivo ressarcimento, a contradição com as normas do direito interno posterior torna-se intolerável. Acabando por concluir que as normas que fixavam este limite máximo para a indenização, ainda que afastáveis em caso de dolo e culpa grave, não eram de nenhuma maneira conciliáveis com o princípio constitucional do direito à inviolabilidade do homem, devendo, pois, esta inconstitucionalidade ser declarada pelo Judiciário, mesmo se a origem da norma era uma Convenção internacional."

O conflito aconteceria com a norma constitucional do direito à inviolabilidade do homem, presente no art. 2 da Constituição Italiana, e não com o princípio de proteção aos consumidores, pois tal norma inexistia na Constituição italiana, mesmo assim a contradição intrínseca entre as matérias não deixou de ser aventada.

Tito BALLARINO chega a afirmar que a decisão da Corte Constitucional (Arrêt $\mathrm{n}$. 132, de 16 de maio de 1985) abrogou a regra da Convenção relativa a limitação da responsabilidade em caso de morte do passageiro, por violação ao direito fundamental à integridade da pessoa humana. A corte teria examinado também o problema do tratamento inequitativo entre os passageiros do avião e os passageiros de outros meios de transporte e concluído que aqueles não deveriam sofre restrições a seus direitos fundamentais, em virtude da limitação permitida pela lei ordinária que recebeu a Convenção. ${ }^{78}$

c) A reaşão na Alemanha e o controle do conteúdo e equidade do contrato de transporte aéreo Se os Estados Unidos, país precursor da responsabilidade objetiva, interessou-se na administração Kennedy pela proteção mais efetiva de seus cidadãos, a Alemanha, país de grande tradição no cumprimento do princípio de boa-fé nas obrigações e no conseqüente amplo controle judicial do conteúdo dos contratos, não poderia deixar de fornecer um outro exemplo, que merece ser analisado.

Em 1983, o Tribunal Federal Alemão (B.G.H.) declarou seis cláusulas presentes no contrato oferecido pela Lufthansa para vôos internacionais como abusivas, e portanto, proibidas, determinando a sua não mais utilização, apesar de todas estas normas constarem da Sugestão-Resolução n 1013 da IATA. ${ }^{79}$ Dois aspectos foram especialmente analisados pelo Tribunal superior da Alemanha: se o fato de uma cláusula contratual encontrar aplicação em vários países ou aplicação "internacional" impediria o controle judicial de sua abusividade ou não; e a relação, em direito alemão, entre as normas da Convenção de Varsóvia e as normas da famosa lei alemã de controle das cláusulas contratuais gerais, a AGB-Gesetz ${ }^{80}$

Sobre o primeiro aspecto concluiu o B.G.H. que o fato da claúsula presente nas condições gerais do contrato da empresa aérea ser "universal", ou encontrar utilização em vários países, não impede o seu controle pelo Judiciário, quanto ao respeito dos direitos do "cliente" (consumidor) de ver tornadas sem efeito as cláusulas abusivas. A "internacionalidade" das cláusulas usadas pelas empresas de aviação não as torna incontroláveis pelo Judiciário de cada país $^{81}$ e as empresas devem contar com a possibilidade das associações de defesa dos consumidores entrarem com ações coletivas nos mercados mais relevantes, devendo, portanto, adaptá-las ao nível legal de proteção do cliente-consumidor, se pretendem a elas recorrer frente ao Judiciário e à Administração.

No segundo aspecto analisado, a relação entre as normas da Convenção de Varsóvia e a lei interna sobre Condições Gerais dos Contratos, a AGB-Gesetz, as conclusões do Tribunal foram fiéis tanto à doutrina alemã de Direito Internacional Público e Direito Comunitário, de Dualismo conjugado com o Dogma de uma certa superioridade da 
norma de origem em atos internacionais, especialmente das normas oriundas da $\mathrm{Co}$ munidade Européia, quanto também a nova tendência de proteção do cliente-aderente.

^O Tribunal concluiu que existe uma equivalência entre as fontes da Convenção de Varsóvia e da AGB-Gesetz, pois as normas da Convenção só vigoram internamente $n$ Alemanha graças a sua transformação e incorporação no ordenamento jurídico interno.

Conclui, igualmente, que no campo de aplicação material da Convenção goza esta de uma supremacia, tendo em vista a regra de interpretação aceita na Alemanha, que "na dúvida deve-se aceitar, que o legislado nacional não quis contrariar anteriore obrigações internacionais assumidas pelo país". ${ }^{82}$ Passando então a concentrar suas atenções no campo de aplicação efetivamente pretendido pela Convenção.

Segundo o B.G.H. alemão, a pergunta chave sobre a relação da Convenção de Varsóvia e a AGB-Gesetz é se a Convenção estabelece, nos casos que se incluem em seu campo de aplicação material, de maneira exclusiva e final (abschliessend) as diferença entre cláusulas contratuais permitidas cláusulas contratuais proibidas ou se estabelece somente as cláusulas contratuais mínimas para a proteção do transportado, deixando campo para uma proteção maior do cliente-consumidor, através da ação do direito nacional. ${ }^{83}$

As opiniões dividem-se especialmente porque os trabalhos da Convenção de Varsóvia não enfrentaram diretamente o tema. De um lado, defendem uns que a possibilidade do cliente estabelecer cláusulas ou condições especiais para ele (por exemplo, um limite maior para a responsabilidade) lembra a posição supletiva das normas da Convenção, as quais, portanto, estabeleceriam um mínimo a ser seguido em caso de ausência de manifestação da vontade individua ou da manifestação estatal imperativa. Outros, porém, lembram a função harmonizadora, universalizadora das normas da Convenção, e concluem que esta função indica que as normas pretendiam regular os caso de forma exclusiva e final (abscbliessend) ${ }^{84}$ 148
O tribunal alemão optou, portanto, para resolver o conflito, em executar uma análise atenta e diferenciada do campo de aplicação das normas, acabou distinguindo entre cláusulas presentes nos contratos que simplesmente repetem ou declaram aplicável as normas da Convenção de Varsóvia e entre cláusulas outras, não meramente declaratórias. Conclui, então, que as cláusulas meramente declaratórias, seriam regidas exclusivamente pela Convenção de Varsóvia tendo em vista o dogma da superioridade anteriormente mencionado, o que afastaria a aplicação da lei nacional de proteção contra cláusulas abusivas. Mas todas as outras cláusulas presentes nos contratos aéreos recairiam no campo de aplicação da lei nacional e da Convenção, que não as regularia de forma final e exclusiva (abschliessend) logo, o Tribunal a submeteu ao controle da AGB-Gesetz e declarou seis delas sem efeito frente ao consumidor. ${ }^{85}$

d) Reação no Brasil

No Brasil, a reação contra os patamares limitados de indenização fixados pela Convenção de Varsóvia foi, até 1988, muito reduzida, pois a jurisprudência brasileira não ra aberta a teses de inconstitucionalidade e mantinha-se fiel ao entendimento da superioridade dos Tratados face às leis ordinárias posteriores. ${ }^{86} \mathrm{~A}$ única reação foi no sentido de interpretar de forma aberta a noção de culpa grave ou dolo, que retira o privilégio da limitação da responsabilidade. ${ }^{87}$

Em se tratando de norma anterior a nova Constituição, o Código Brasileiro de Aeronáutico teve de ser recebido no novo ordenamento jurídico nacional. Os doutrinadores brasileiros, ao contrário dos italianos, nada mencionam sobre os eventuais aspectos de conflito das normas do CoBA, que imitam a responsabilidade do transportador a patamares considerados baixos e os princípios constitucionais que asseguram o direito à inviolabilidade do homem, direito à vida (caput do art. $5^{\circ}$ da CF de 1988) direito à proteção do consumidor (inciso XXXII do art. 50 da CF de 1988).
Seja pela especialização do tema ou pelo pequeno número de acidentes fatais envolvendo o transporte aéreo nos dias de hoje, a tese, salvo melhor juízo, permanece adormecida no cenário nacional. No sistema anterior de responsabilidade subjetiva baseada na culpa, a simples inversão do ônus da prova permitida pelo sistema aeronáutico, já era considerada uma vantagem. Mas, tratando-se de norma interna, o CoBA obviamente submete-se aos novos parâmetros ditados pela Constituição de 1988 e às normas que complementam estas novas linhas do direito nacional. Parece-nos, portanto, que se o valor da indenização realmente é ínfimo, face às perdas efetivamente ocorridas (morte do pai de família, morte do filho único etc) e face a atual aceitação do dano moral, tanto na Constituição, como no próprio Código de Defesa do Consumidor, a tese da inconstitucionalidade ou do não-recebimento de determinadas normas do CoBA poderá vir a ser sustentada em nosso país.

Neste caso vale lembrar os ensinamento dos doutrinadores italianos ${ }^{88}$, que propunham ao invés da decretação da inconstitucionalidade uma interpretação conforme à Constituição, isto é, uma interpretação que utilizando outras normas do sistema pudesse evitar os excessos do limite de responsabilidade, que o tornariam inconstitucionais.

Parece-nos que foi com a entrada em vigor do $C D C$ que os consumidores-vítimas de acidentes de aviação conscientizaram-se de seus novos direitos e forçaram uma to mada de posição da jurisprudência, ainda restrita ao primeiro grau de jurisdição. A antinomia entre o CDC e as normas especiais aeronáuticas deve ser analisada em detalhes, assim como a possibilidade de uma solução "conforme a Constituição", isto é conforme os novos valores básicos impostos pela ordem constitucional.

B) $A$ responsabilidade (efetiva) pelo fato do serviço segundo o Código de Defesa do Consumidor

No estudo da responsabilidade pelo fato do serviço imposta pelo CDC destacaremos a finalidade das normas do $C D C$, no que tange à responsabilidade civil e à saúde e segurança dos consumidores, para facilitar sua interpretação teleológica, examinando igualmente a posição hierárquica destas normas frente as outras do sistema.

Destacaremos, igualmente, o método escolhido pelo CDC para assegurar o seu novo valor de proteção dos consumidores, e, por fim, analisaremos a natureza, elementos e extensão desta responsabilidade.

\section{Características}

a) Finalidade e Hierarquia das normas do $C D C$

A entrada em vigor do Código de Defesa do Consumidor (CDC) tem como objetivo alcançar a "transparência e a harmonia das relações de consumo", assegurando "o atendimento das necessidades do consumidor, o respeito a sua dignidade, saúde e segurança, a proteção de seus interesses econômicos" (art.4으, caput $\mathrm{CDC}$ ).

Trata-se de uma lei de função social, imperativa e renovadora, como expusemos. Sua finalidade é um tratamento especial para o consumidor, enquanto agente mais vulnerável no mercado, de forma a alcançar o reequilíbrio das relações de consumo, rompendo com a valorização excessiva da autonomia da vontade dos indivíduos e seus reflexos limitadores à ação do Direito na esfera privada. A nova lei assegura novos direitos ao consumidor e impõe novos deveres aos fornecedores de produtos e serviços, de forma a assegurar a boa-fé e a harmonia nas relações no mercado.

Para tanto o art. $1^{\circ}$ do CDC declara as normas do Código como normas de ordem pública, inderrogáveis pela vontade individual.

Se a vontade individual, expressa no contrato entre fornecedor e consumidor, não pode derrogar os novos direitos e deveres impostos pelo $\mathrm{CDC}$, poderá uma lei anterior afastar a incidência do CDC, em matéria que ele pretende impor seu novo equilíbrio?

O CDC cumpre o mandamento Constitucional do artigo $5^{\circ}$, inciso XXXII, que 
inclui entre os direitos fundamentais no Brasil, a proteção do consumidor e o mandamento do art. 170 da Constituição de 1988, o qual considera princípio da ordem econômica brasileira a defesa do consumidor.

A lei máxima, o ápice do sistema jurídico dos países democráticos é, atualmente, a Constituição. ${ }^{89}$ Nos séculos XVIII e XIX, tendo em vista a "fraqueza jurídica" $\mathrm{da}$ Constituição frente ao Liberalismo dominante e às relações de força na Sociedade, possuía esta uma função meramente negativa (a limitar o Estado). O centro do sistema era representado pelas codificações, pelo Código Civil, com sua força científica, sistemática e completa, representando a própria evolução da ciência do Direito. $O$ intervencionismo Estatal, a publicização do Direito Privado no séc. XX e idéia de Estado Social resultaram no reconhecimento de uma função positiva da Constituição, a determinar não só a abstenção do Estado, mas sua ação, a transfigurar e impregnar como medida normativa todo o sistema do Direito. ${ }^{90}$

É da Constituição Federal de 1988, por exemplo, que emanam hoje os princípios basilares a serem seguidos pelas leis inferiores e as linhas éticas de conduta que determinarão, em última análise, a coerência do sistema e a elaboração e interpretação das outras leis. É o que o mestre alemão HESSE denominou "força normativa da Constituição", força determinante do conteúdo das futuras leis, força transfiguradora, força modificadora das leis anteriores recebidas no novo sistema, força determinante da interpretação "conforme a Constituição" (verfassungsmässige Auslegung) das leis anteriores. $^{91}$

A ordem constitucional serve como medida normativa do sistema e, nesse sentido, suas normas e seus princípios atuam como limitadores na aplicação das leis e não se submete aos critérios normais que determinam a vigência e a eficácia das leis no tempo. A ordem constitucional, portanto, é o primeiro dos fatores e o hierarquicamente mais forte a ser considerado pelo aplicador 150 da lei. A Constituição brasileira de 1988 estabeleceu como princípio e direito fund mental a proteção do consumidor e indicou a elaboração, inclusive, de um Código de Defesa do Consumidor, em suas disposições transitórias, tendo em vista o baixo nível de proteção assegurado pela legislação então existente e a necessidade de renovar o sistema, através de nova lei de função social.

A Constituição ordena a proteção do consumidor, presumido agente mais vulnerável do mercado, através da lei. Note-se que o CDC concretiza esta proteção, mas não reivindica para si a exclusividade total na proteção legal do consumidor, afirmando em seu artigo $7^{\circ}$, caput, que "Os direitos previstos neste Código não excluem outros decorrentes de tratados ou convenções internacionais de que o Brasil seja signitário da legislação interna ordinária, de regulamentos expedidos pelas autoridades administrativas competentes, bem como dos que derivem dos princípios gerais do direito, analogia, costumes e eqüidade."

A expressão utilizada no CDC é clara não reivindicando a exclusividade dos " $\mathrm{di}$ reitos" concedidos ao consumidor. Outra será a posição se o Tratado ou lei retira, limita ou impõe a renúncia aos direitos que o sistema do CDC assegura ao consumidor. Neste caso a aplicação do CDC é determinada pelo fato de ser o corpo de normas que assegura, segundo os novos parâmetros e valores orientadores, eficácia ao mandamento constitucional de proteção do consumidor. Assegura-se, em última análise, através da norma do art. $7^{\circ} \mathrm{CDC}$, a aplicação da norma que mais favorece o consumidor. ${ }^{92}$

A nova lei reconhece que é direito básico do consumidor a proteção de sua "vida, saúde e segurança', assim como a efetiva "prevenção e reparação" dos danos patrimoniais e morais sofridos no mercado (art. 6 I e VI do CDC). Ao incluir na lista de direitos básicos a reparação efetiva dos danos sofridos pelo consumidor, inclusive os danos morais e não só os danos patrimoniais, está o CDC a valorar de forma definitiva a importância da reparação, como forma de reequilibrar a relação de consumo, conturbada pela ocorrência do dano. A reparação dos danos sofridos pelo consumidor têm, no sistema do CDC, tripla função, como veremos, ${ }^{93}$ função preventiva, função compensatória e função satisfativa.

b) Método de imposição da responsabilidade Antes de analisarmos os elementos da responsabilidade imposta pelo $\mathrm{CDC}$, convém relembrar que o método escolhido pelo legislador do CDC para alcançar as finalidades protetivas antes mencionadas foi o da imposição de novos deveres legais.

Destacamos a especialidade do método escolhido pelo CDC, pois, se a lista do art. 6 do CDC traz os "direitos" que podem se subjetivar no consumidor. O desenvolvimento de todos estes direitos no corpo do CDC será de forma a impor "deveres legais" ao fornecedor, assegurando assim ao consumidor (e aos órgãos auxiliares, públicos e privados) a possibilidade de compelir aquele fornecedor que está contrariando a norma objetiva a cumprí-la, através de ações coletivas e ações individuais. ${ }^{94}$

Ao mesmo tempo, o método de imposicão de deveres legais retira do consumidor o poder de (através de contrato) liberar o fornecedor de seu dever. ${ }^{95} \mathrm{O}$ dever é legal, uma vez que imposto por norma jurídica, norma de ordem pública, logo, indisponível por vontade das partes.

Útil, igualmente, é lembrar a figura de linguagem utilizada por LARENZ ${ }^{96}$, o qual representa a obrigação como um objeto material, que projeta naturalmente uma sombra. A sombra é a responsabilidade, ligada de forma essencial à obrigação imposta ao agente. Assim, se quisermos saber quem é o responsável legal teremos de observar quem a lei imputou à obrigação ou o dever, se quisermos saber a extensão ou a possibilidade de limitação da responsabilidade, teremos de observar que tipo de obrigação (contratual, por ato ilícito, legal etc) vinculava o agente responsabilizado.

A figura criada por LARENZ facilita compreensão dos diferentes regimes da responsabilidade contratual e extracontratual, pela simples observação que sua origem é diferente, logo, a sua projeção ou sombra terá características diferenciadas; facilita, igualmente, compreender a evolução da responsabilidade extracontratual, a qual baseiase na imposição de deveres, na imputação objetiva (independente da culpa e mesmo do risco concreto da atividade) a um agente econômico. Impor deveres jurídicos é criar obrigações e, portanto, imputar também a responsabilidade pelo descumprimento da obrigação legal (Wer schuldet, haftet auch).

c) Natureza objetiva da responsabilidade $e$ elementos

A idéia orientadora do CDC de assegurar a qualidade adequada e a segurança dos produtos e serviços prestados ou oferecidos à população (art. 4, V do CDC) levou o legislador a positivar não só um dever geral de informação (art. 9 e seguintes do CDC), mas, principalmente, a agravar o dever de segurança na prestação de serviços e no fornecimento de serviços (art. 14, 12 e seguintes do CDC). Introduziu o legislador assim normas prevendo um novo caso de responsabilidade objetiva, uma responsabilidade "não-culposa". 97

A norma central no caso da prestação de serviços no mercado é o art. 14, o qual dispõe que: "O fornecedor de serviços responde, independentemente da existência de culpa, pela reparação dos danos causados aos consumidores por defeitos relativos à prestação dos serviços, bem como por informações insuficientes e inadequadas sobre a fruição e riscos."

A responsabilidade é objetiva, pois prescinde não só da prova, como da própria discussão sobre a culpa. A responsabilidade legal imposta concentra-se não somente na atividade de risco do fornecedor, mas sim, principalmente na existência do defeito e no nexo causal entre o defeito e o dano.

Segundo dispõem os parágrafos $1^{\circ}$ e $2^{\circ}$ do art. 14: "O serviço é defeituoso quando não fornece a segurança que o consumidor dele pode esperar, levando-se em consideração as circunstâncias relevantes, entre as quais: I - o modo de seu fornecimento; II - 
o resultado e os riscos que razoavelmente dele se esperam; III - a época em que foi fornecido." "O serviço não é considerado defeituoso pela adoção de novas técnicas."

Como podemos observar, em princípio a assustadora responsabilidade objetiva é relativizada pela importante noção de defeito. $O$ fornecedor tem o dever de prestar um serviço com a segurança que dele se espera. Se houve defeito no serviço, ele descumpriu seu dever de segurança e será responsabilizado, sem perquirirmos de sua culpa ou da de seus prepostos, sem considerarmos mesmo a ocorrência de um "caso fortuito" interno, que levou a existência do defeito, ainda na esfera de competência do fornecedor do serviço. As possibilidades de exoneração são as do $\S 3^{\circ}$ do art. 14 , isto é, quando o fornecedor conseguir provar: "I que tendo prestado o serviço, o defeito inexiste; II - a culpa exclusiva do consumidor ou de terceiro."

Sem dúvida, se houve defeito em seu serviço, a prova da culpa exclusiva do consumidor ou do terceiro será uma prova "diabólica", assim como também não será fáci a prova da inexistência de defeito, se o acidente, se o dano efetivamente ocorreu (peritus spondet artem suam). Mesmo assim, a nova noção de defeito deve ser destacada, porque procura uma solução mais justa para o caso concreto, diferente daquela oferecida pela teoria tradicional da responsabilidade objetiva, baseada no simples risco da atividade do fornecedor (cujus commodum, ejus periculum).

O agente responsável pela reparação é o fornecedor do serviço, sem que a norma do art. 14 CDC siga o modelo dos artigos 12 e 13 do CDC, que imputam a um agente econômico a responsabilidade principal e a outros uma responsabilidade subsidiária ou por casos específicos. $\mathrm{Na}$ ausência de especificação vige o artigo $3^{\circ}$, o qual define fornecedor de serviço como toda pessoa física ou jurídica que desenvolve a atividade de prestar serviços; sendo que o $\S 2^{\circ}$ deste artigo define serviço como "qualquer atividade fornecida no mercado de consumo, mediante remuneração, inclusive as de na- tureza bancária, financeira, de crédito e securitária, salvo as decorrentes das relações de caráter trabalhista." Esta definição ampla de prestador de serviços pode incluir, portanto, o transportador aéreo. A única exceção subjetiva ao sistema objetivo de responsabilidade pelo fato do produto é aquela do $\S 4^{\circ}$ do art. 14 que assegura aos profissionais liberais, que sua responsabilidade pessoal será apurada mediante a verificação de culpa, logo, no sistema tradicional de responsabilidade subjetiva, contando o consumidor, no máximo, com a determinação pelo juiz da inversão do ônus da prova.

\section{d) Extensão da responsabilidade}

Por fim, cabe examinar a extensão $d a$ responsabilidade imputada, isto é, seus limites subjetivos, quantitativos e temporais.

Ocorrido o dano em virtude do serviço defeituoso prestado pelo fornecedor este responde objetivamente pela reparação não só dos danos materiais (perdas e danos tradicionais), mas também dos danos imateriais (pretium doloris).

No sistema do CDC, o fornecedor fica obrigado a reparar de maneira efetiva (art. $6, \mathrm{VI}$ ) os danos patrimoniais e morais que ocasionou. A tendência do direito atual é o princípio da indenização integral, aliado ao princípio da socialização dos custos da reparação, ao imputar a responsabilidade de maneira objetiva ao agente econômico que melhor pode diluir os custos (através dos preços e dos seguros) na sociedade como um todo. ${ }^{99}$

Este sistema por alguns chamado de "canalização" ou alocação dos custos ${ }^{100}$ e pode e deve ser complementado pelo recurso aos seguros, pois através dos seguros os encargos também fracionam-se sob forma de prêmio e contribuições. ${ }^{101}$

A responsabilidade imposta pelo CDC segue o princípio da indenização integral, tanto que o legislador preocupou-se em mencionar expressamente os danos "morais" ou extrapatrimoniais. A reparação devida é limitada ao dano sofrido (patrimonial ou extrapatrimonial), mas a responsabilidade é teoricamente ilimitada.
O dano é a diminuição ou subtração de um bem jurídico. ${ }^{102} \mathrm{O}$ dano patrimonial é aquele que atingido o patrimônio da vítima, pode ser reduzido pecuniariamente. ${ }^{10}$ Já o dano moral é aquele que não atinge ao patrimônio e causa tão somente uma dor moral à vítima, ${ }^{104} \mathrm{em}$ última análise viola um interesse extrapatrimonial protegido pela ordem jurídica. ${ }^{105}$

Nota-se com a inclusão do dano moral na obrigação de reparar, que o direito aceita cada vez mais as finalidades subsidiárias da reparação. A reparação não visa somente volta ao status quo ante, o que seria impossível no dano moral, ou a compensação pura e simples dos danos. A reparação possui uma importante função preventiva, no sentido de chamar atenção dos agentes para as possíveis conseqüências de suas atividades ou falhas, uma importante função com pensatória, para equilibrar a posição do sujeitos envolvidos pelo dano, mas possui também uma função satisfativa (Genug tuungsfunktion).$^{106} \mathrm{~A}$ reparação do dano moral é satisfativa no sentido que se não pode repor o status quo ante pode amenizar a do o sofrimento da vítima, é satisfativa pois demonstra à vítima e à coletividade que dano originou uma resposta jurídica, um diminuição no patrimônio do agente responsável.

Tendo em vista este novo caráter da reparação, não é de se espantar que a responsabilidade pelo fato do produto imposta pelo CDC deva levar a uma "reparação efetiva" do dano sofrido pelo consumidor-vítima (todas as vítimas são equiparadas ao consumidor, segundo dispõe o art. 17 do $\mathrm{CDC}$ ) e que tendo em vista o caráter de norma de ordem pública da previsão, qualquer exoneração ou limite a esta responsabilidade, estabelecido a priori através do contrato, seja considerado ineficaz. ${ }^{107}$

$\mathrm{O}$ art. 25 do CDC completa o quadro, ao dispor que fica "vedada a estipulação contratual de cláusula que impossibilite, exonere ou atenue a obrigação de indenizar prevista" tanto na seção sobre o vício, como na seção sobre o fato do produto e do serviço no CDC.
Por fim, cabe mencionar os limites temporais impostos pelo CDC em seu artigo 27. $O C D C$ instituiu um prazo prescricional de 5 anos, a contar, porém, do "conhecimento do dano e de sua autoria" para a pretensão à reparação dos danos por fato do serviço ou por fato do produto.

2. A força renovadora do Código de Defesa do Consumidor e a solução das antinomias por ele criadas

A exposição até agora executada permite-nos considerar o CDC como verdadeira lei de função social, como um micro-sistema orientador introduzido pelo legislador para alcançar um objetivo: uma nova harmonia, lealdade e transparência nas relações de consumo. O CDC apresenta, assim, uma grande força renovadora. Mais do que determinar a revogação, a perda de vigência, de outras normas anteriores (gerais ou especiais), parece-nos que o CDC ocasionará uma nova interpretação das antigas normas, quando a relação for de consumo e ambas as normas encontrarem aplicação. Não sendo possível esta compatibilização entre a normas do CDC e as normas anteriores, deverá o intérprete optar por um dos sistemas, solucionando a antinomia.

A posição do CDC como lei especial-subjetiva, lei posterior e hierarquicamente superior, como lei de ordem pública e complementar ao mandamento constitucional, assegurarão a força necessária renovadora. Mas a solução das antinomias é uma atividade casuística e porque não dizer, subjetiva.

Neste trabalho examinamos apenas a antinomia entre as normas que permitem e as que proíbem a limitação, através de cláusula no contrato de consumo, da responsabilidade pelo dano à saúde e à segurança do passageiro, a antinomia entre as normas que prevêem uma responsabilidade subjetiva limitada e as que impõem uma responsabilidade objetiva sem limites, a não ser a do dano sofrido e seu efetivo ressarcimento. A análise realizada nos permitiria concluir pela escolha das normas do CDC, como prevalentes, se presente na relação um con- 
sumidor, vulnerável, face a utilização dos critérios clássicos, cronológico, hierárquico e da especialização, afastando-se assim as normas que determinam uma alocação de custos a ser suportada pela vítima.

Se o intérprete, ao contrário, considerar que a utilização dos critérios não resultar na clara determinação da norma que dever prevalecer, poderá igualmente utilizar uma terceira fonte, no caso a lei máxima do sistema, a própria Constituição, examinando no caso concreto se as leis em contradição cumprem com a determinação de proteção do consumidor "segundo a lei" e protegem suficientemente os outros valores protegidos pela Constituição, como o direito à vida, à inviolabilidade pessoal, à propriedade etc.

Este trabalho, tornado extenso pelo interesse do tema, pretendia apenas expor problema, examinar os critérios e instrumentos colocados à disposição do aplicador da lei face às antinomias criadas pela entrada em vigor do CDC. Sendo assim, não incluímos uma conclusão stricto sensu, ma apenas algumas observações finais (e pessoais) sobre a força renovadora do novo Código. Parece-nos, efetivamente, que o legislador quis e criou uma lei de função social, que trará como resultado a necessária adaptação do sistema aos seus novos valores, agora positivados.

Espera-se que esta modificação se faça com a harmonia e o equilíbrio social que o próprio CDC deseja, através da ação consciente de advogados, juízes e do ministério público.

Como ensina Oscar TENÓRIO, a vida das normas jurídicas não é eterna; elaboradas para as relações dos homens em sociedade, têm o seu destino condicionado ao substractum social que elas disciplinam e or denam. ${ }^{108}$ As mudanças na sociedade mais cedo ou mais tarde refletem em mudanças na legislação em vigor ou em uma nova interpretação dada a normas anteriores ${ }^{109}$; a própria sobrevivência de normas "antigas" é um sinal de seu valor e da sabedoria das novas linhas de interpretação impostas pelo Judiciário e pela doutrina. ${ }^{110}$
Notas

1 in: Daños, Mosset Iturraspe, J. e outros, Ed. Depalma, Buenos Aires, 1991, pg. 114

2 todo o Direito têm função social, o Direito é parte da estrutura da sociedade, é um de seus sistemas parciais, logo a expressão que estamos utilizando "lei de função social", deve ser entendida não como uma repeticáo petçao da propra essencis como destaque de uma caracteristica impar de determinadas leis. Sao leis intervencionistas, leis de ordem pública econômica, que procuram realizar o que Jhering denominava funçao social do direito privado (veja-se Larenz, Karl, Metodologia da ciência do Direito, trad., Lisboa, Fundação Gulbenkian, 1969, pg. 47), veja-se tb. o excelente ensaio de sociologia, economia e direito do professor de Hamburgo Adams, Michael, Normen, Standards, Rechte, in: JZ, Juristen Zeitung (Tübigen), 1991, pgs. 941 a 955

${ }^{3}$ Como ensina Niklas Luhman nem sempre as "noções valorativas orientadoras de uma sociedade costumam ser codificadas juridicamente no sentido positivo e técnico (Sociologia do Direito II, trad. Gustavo Bayer, Rio de Janeiro: Ed. Tempo Brasileiro, 1985, pg. 121), é esta uma nova tendência do legislador moderno, que funa assim assegurar a realizaça dos novos direitos dä (vejase Consivica Federal de 1988 e cidadãos (veja-se a Constituição Federal de 1988 e as leis que a complementam)

veja, por todos, Westermann, Hans-Peter, Sonderprivatrechtliche Sozialmodelle und das allgemeine Privatrecht, in: Archiv für die civilistische Praxis, vol. 178 (1978), pg. 151-226, em que o autor enfrenta o tema da modificaçõa do modelo social na sociedade no século XX, da influência das idéias intervencionistas do direito público moderno, a conseqüente criação de micro-sistemas
de leis sociais para a proteção dos "mais fracos", e o relacionamento e influência destas leis especiais com o direito privado geral.

Sobre a função de transformação social destas leis Sobre a função de transformaçào social destas leis
imperativas, veja Kramer, Ernst, Die Krise des Liberalen imperativas, veja Kramer, Ernst, Die Krise des Liberalen
Vertragsgedankens, Munique: Fink V., 1974, pgs. 37 e ss 5 como afirma G. Ripert, "É preciso um grande idealismo para sonhar com a transformação da sociedade pelo direito", mas constata: "Legislar para progredir, tal é a regra de conduta que se impõem aos governantes democráticos." ( $O$ Regime Democrático e o Direito Civil Moderno, trad. J. Cortezão, São Paulo: Saraiva, 1937, pg. 48), sobre as relações Direito e Força, veja-se Bobbio, N. Teoria do Ordenamento Jurídico, trad. M.C.L. dos Santos, Brasilia: Ed. Polis/UnB, 1990, pg. 65 ss.

${ }^{6}$ O Superior Tribunal de Justiça, em decisão de 11 de setembro de 1990, REsp. 3.683-SP, $4^{2}$ T., examinou o tema do efeito imediato e da caracterização de uma lei como de ordem pública econômica, veja in: RT 661/199-203, assim tb. o Tribunal de Alçada de São Paulo, in: RT 665/119
7 cite-se aqui os artigos de Carvalho, Luis C.P. de, $O$ Código do Consumidor e o Direito Aeronáutico, in: RT 673/47 comentando posiçōes de Benjamin, Antônio H.V. de, in: Comentários ao Código de Protesão ao Consumidor, J. de Oliveira (Coord.), Saraiva, 1991, pg. 78 ${ }^{8}$ Daños, obra coletiva já citada, pg. 114

9 para Ghersi, Carlos Alberto, Reparación de Daños, Buenos Aires: Ed. Universidade, 1989, pg. 34 e 35, a idéia central da responsabilidade é a reparação, tendo em vista: la necesidad de conservación individual y social de los bienes y servicios, desde un punto de vista económico - por su escasez y alto costo de reposición, y el respeto al ser bumano, por su sola existencic

10 veja, por todos, IRTR, Natalino, L'etá della decodificazion Milão; Giuffré, 1989 e De Cupis, Adriano, It diritto civile nella sua fase attuale, in Riv. Dir, Comm. vol. LXVIII, pg. 421-440

11 no dizer de Vicente Ráo, o conflito de leis no tempo um conflito de competências, um conflito material (O Direito e a Vida dos Direitos, vol. I, T. II, pg. 4450 apud Batalha, W. Direito Intertemporal, Rio de Janeiro: Forense, 1980, pg. 187

12 como ensina Rugiero, Roberto de. Instituiḡóes de Direito Civil, vol. I, trad. Ary dos Santos, São Paulo: Saraiva 1935. pe.164, "A pergunta: 'dada uma relacão jaraiva, 1935. pg. 164, "A pergunta. 'dada uma relaçào je à outra e inversa: 'dada uma norma jurídica, quais as reções que por th são reguladas" "uve assuais as relaçōes que por ela sáo reguladas?"...que assumem importancas quando se levarte divida sobre a escolh "entre duas normas diferentes pertencentes ao mesmo
sistema, mas emanadas sucessivamente." ${ }^{13}$ da análise das Disposições Transitórias do CDC, Lei $8.078 / 90$, observa-se que ficaram revogadas expressamente somente algumas normas da Lei $7.347 / 85$, que dispõe sobre a ação civil pública, e substituídas por novas normas introduzidas pelo $C D C$

${ }^{14}$ Oscar Tenório, comentando a norma do art.2 caput da UCC de 1942, a firma: "revogar uma lei significa da LICC de 1942, afina: "revogar uma lei significa tirar-lhe a força obrigatoria", revogar "é fazer outro direito, fulmina obrig que vigorava", se a vigencia e vida das normas juridicas, nao é esta eterna, e a revogação é o processo ténico para tirar a vida das leis Rio de Janeiro: Borsói, 1955, pgs. 71, 64 e 65

15 veja-se a obra coordenada por Perelman, Ch. Les Antinomies en Droit Bruxelas: Bruylant, 1965, trazendo as definições de Malgaud, pg. 7, Vander Elst, pg. 138, Salmon, pg. 285, Szabó e pg. 350, Buch, pg. 373; ou, em português, a obra de Norberto Bobbio, Teoria do Ordenamento Jurídico, trad. Maria C.C. Leite dos Santos, Brasilia: Polis/UnB, 1990, pg. 71 e ss

${ }^{16}$ veja-se a obra cit. de Perelman, Les Antinomies..., em especial a posição de Malgaud, W. in: Les antinomies en droit-apropos de l'étude de G.Gavazzi, pg. 7 a 18, afirmando que no caso dos conflitos, como o sistem oferece as soluções (em nosso caso, a LICC) não podemos utilizar a expressão antinomia. A solução da ant- nomia seria a ação normal do intérprete, a solução dos conflitos viria do próprio legislador.

17 Oscar Tenório ob́ cit pg. 64 e 65

18 veja Bobbio, Teoria, ob. cit., pg. 90

19 assim Bobbio, Teoria, ob. cit., pg. 92

${ }^{20}$ veja sobre o critério hierárquico Bobbio, Des Crité-

res. pg. 255 e ss e sobre normas de ordem pública,

Serpa Lopes, MM Comentário Teórico e Prático da Le de Introdusão ao Código Civil, vol. I, Rio de Janeiro: Ed. Jacintho, 1943, pgs. 33 e ss

21 veja a obra de Tenório, ob. cit., pg. 86, que já em 1955 reconhecia a superioridade da Co ainda considerava o Tratado como obra (exclusiva) do Executivo, só podendo por este ser revogado, veja em posição contrária, visualizando o Tratado como obra conjunta (como as leis) do Executivo e do Legislativo, Medeiros, Antônio Cachapuz de, $O$ Poder Legislativo e A 1983

22 a tendência atual é justamente de aproximação entre o Direito Internacional Público e os valores protegidos pelas Constituições nacionais. O Direito Internacional público evoluiu de sua fase jusnaturalista para um "realismo não conformista", reconhecendo sua falta de força frente as constituiçōes nacionais, mas buscando linhas de contato e valores éticos comuns, veja a excelente e realista exposição de Visscher, Paul de. Les Tendances Internationales de Constituitions Modernes in: Recueil des Cours, 1952, I. Paris: Sirey, Pg. 515 a 576

23 interessante observação monista é feita por Celso Ribeiro Bastos, in: Comentários à Constituicão Federal de 1988; Saraiva, 1988, vol. 2, comentário ao $\S 2^{\circ}$ do art. $5 \mathrm{da}$ CF. A tese monista ajudaria também a aceitar as normas elaboradas por um órgão supracional que controlasse a integração econômica dos países do Mercosul, nos moldes da Comunidade Econômica Européia, na realidade atual, porém, tal órgão com competências autônomas e com força de decisão ainda não existe (talvez ex éc no Tryado definitivo do MERCOSUL em 1994, o que poderia pressupor uma mudança na Constituição de 1988).

24 veja-se os artigos 49 e 84 da Constituição Federal de 1988

25 De Visscher, ob. cit., pg. 563 a 569

26 Rezek, Francisco, in: Interpretaçoes da Constituição Federal de 1988, Coord, Ives Gandra Martins, Fub, Brasilia, 1988, pg. 7

27 veja interessante estudo de Fillipi, Rejane Brasil, Conflito entre Tratado Internacional e Lei Interna Posterior no Tempo, in; Revista AJURIS, $34 / 226$ a 235, no qual conclui, examinando principalmente o GATT, que "não é dificil de acontecer que os paises economicamente mais poderosos utilizem tais acordos como instrumento para aperfeiçoar a sujeição econômica dos, sob a aparência de igualdade, mais fracos... 
28 veja Filippi, Rejane Brasil, Conflito entre Tratado Internacional e Lei Interna posterior no tempo, in: $\mathrm{R}$. AJURIS, n.34, pg. 226 a 235

29 veja decisão do TRF, $1^{2}$ Reg., REO $113919 / \mathrm{BA}$, de 04.03.90, citando o leading case do STF (RE 80.004-SE) e afurmando: "A tradicaa constitucional brasileira, ferentemente de outras ordens jurídicas (Lei Fundamental de Bonn, art. 25) não dá prevalência fund internacional, mesmo após incorporado a legislação interna, em relação a legislação comum..."

30 veja Bobbio, Norberto, Des critéres pour résoudre les antinomies, in: Perelman, ob. cit., pg. 237 a 258

31 veja IRTI, ob. cit. sobre as novas técnicas do legislador, pg. 43 e ss.

32 assim a tese laureada de Dekeuwer-Défossez, Fran coise, Les Dispositions transitoires dans la legislation civite çoise, Les Dispositions transitoires dans

${ }^{33}$ Dekeuwer-Défossez, ob. cit, pg. 4 a 6

34 veja Bobbio, Des critéres, ob, cit. pgs. 253 a 255

35 Bobbio, Des critéres, ob, cit., pg. 255 a 257

36 veja-se o estudo de Luiz Gastão Paes de Barros Leães, "A Responsabilidade do Fabricante pelo Fato do Produto", São Paulo: Ed. Saraiva, 1987

$37 \mathrm{O}$ novo Código ao definir consumidor como aquele que adquire ou utiliza produto ou serviço, assegurou a sua proteção especial tanto para o consumidor pre sente em relaçōes de consumo que envolvem a aquisição $\mathrm{e} o$ uso de produtos, quanto àquelas que envolvem ou visam a simples utilização de serviços; assim os arts. $2^{\circ}$, caput e $3^{\circ}$, caput e $\S 2^{\circ}$ do CDC

38 sobre as características do transporte aéreo intern cional, veja Mattos, J.D. Fairbanks Belfort de, O Desas tre Aéreo em Abidjan, na Costa do Marfin, in: Revista de Direito Civil, n.52, pgs. 169 a 172

39 o autor usa a expressão "lei aeronáutica inde pendente", veja "As Disposiçōes Gerais do Código Brasileiro de Aeronautica. Visào Critica", in: Revista Direito Civil, n. 42, pg. 95

40 as normas do Código Brasileiro de Aeronáutica, por exemplo, sobre a conclusão de contratos com os consumidores são escassas (arts. 227 a 234), mas a mesma lei regula de maneira (etalhada a responsabilida mesma tratual do transportador aéreo (arts. 246 a 261)

41 veja Chaves, $A$. Responsabilidade do Transportador por vias aérea in: Revista de Direito Civil, n. 25, pg.

42 segundo informa Lowenfeld, de 1925 a 1929 The fatality rate was 45 per 100 million passenger miles, contra 0,55 fatalities per 100 million passenger miles in 1965; ve Lowenfeld, Andreas e Mendelsohn, Allan, The United States and Warsaze Convention, in: Harvard Law Review vol. 80, 1967. pg. 498

43 veja o excelente e precursor Dias, José Aguiar, Clánsula de não-indenizar, Rio de Janeiro: Forense, 1976, pgs. 195 e ss

44 trata-se aqui da culpa contratual, como indicava art. 84 do "Regulamento dos Serviços da Navegação 156
64 assim Gaja, Giorgio, Recenti vicende della Convenzione tereo Internazionale, in: Rivista di Diritto Internazionale, 1965/95.

65 as palavras são de Tito Ballarino, ob. cit., pg. 332 e

66 assim Lowenfeld/Mendelsohn, ob. cit., pg. 497, 498 e 510, tb. Gaja ob. cit., pg. 95 e 96

${ }^{67}$ Gaja apresenta o texto da denúncia, no original: The United States of America wisches to state that it gives this notification solely because of the low limits of liability for death or personal injury provided in the Warsaw Comor

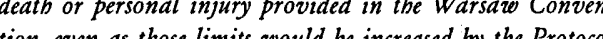
to amend the Convention done at The Hague on September 28,1955, apud, ob. cit., pg. 96

68 assim Lowenfeld/Mendelsohn, ob. cit. pg. 496

69 veja detalhes no relato dos dois delegados norte americanos na Convenção de Montreal Lowenfeld/Mendelsohn, pos. 563,564,566,567 e 570

70 o nome oficial do acordo é Arrangement permittin United States to witbdraw Notice of Termination of War saze Convention, veja detalhes em Gaja, pg. 97

71 CAB, Civil Aeronautics Boardeu (organização norte americana) e IATA, International Air Transport Association (organização mundial de empresas aéreas)

72 assim Lowenfeld/Mendelsohn, pg. 396 a 399, jà informando que também no caso do Canadá seriam criadas normas especiais.

73 texto do bilhete de passagem reproduzido pelos citados autores norte-americanos, pg. 598, contra quebra no sistema de Varsóvia, veja as críticas de GAJA sobre o Arrangement, ob. cit. pg. 103

74 note-se que, em seu artigo, Carvalho, Luiz Camargo Pinto de, ob. cit., pg. 49, ao tentar exemplificar a universalidade da Convenção utiliza o exemplo de uma aeronave fazendo a rota Saso Paulo/Manaus/Mexico, não rotas incluindo cidades norte-americanas, opinando pelo "absurdo" de algumas vitimas se beneficiarem de uma indenização ilimitada (isto é, efetiva, limitada ao dano sofrido) e outras de uma indenização limitada, segundo a Convenção, se todas se encontram na mesma aeronave.

75 assim noticia Ballarino, Tito, ob. cit., pg. 333, nota 63 76 a discussão nasceu em 1978 após uma decisão do tribunal de Roma, veja detalhes em Cannizzaro, ob. cit., pg. 279 e 298

77 veja as conclusões de Cannizzaro, em 1984, ob. cit., pg. 296 a 298, o autor cita as conclusões de Camarda (Profili di illegitimitá constituzionale dell'art. 943 cod na - dell 'art 22 della Comvenzione di Varsavia e dell 'art. 11 del Protocolo dell $A j$ im Diritro arsavia e dell art. 11 del Protocolo dell 'Aja, in Dinillo arno, 1979, p. 1), para o qual bastaria uma aplicaçáo em conjunto das duas nomas, a in tera e a de forte intermizando-as a jurisprudencia e atingindo um patamar razoável e constitucional de proteção do indivíduo, ob. cit., pg. 296 e nt. 50
78 assim Ballarino, ob. cit., pg. 333, com detalhes reproduzidos na nota de n. 63

79 acórdão B.G.H. de 20.1.1983, VII ZR 105/81, publicado na Revista IPRax 1984/316 e os comentários de Lindacher, Walter, Zur Inbaltskontrolle 'internationaler' Flugbeforderungsbedingargen, in: IPRax (Heidelberg) 1984/301

${ }^{80}$ Gesetz zur Regelung des Rechts der Allgemeinen Geschaftsbedingungen (AGB-Gesetz), de 9 de dezembro de 1976; veja, em português, informações sobre a lei em Schwab, Dieter, Validade e Controle das 'Condições Gerais de Negócios, in: Revista AJURIS, n. 41 , pgs. 7 a 20

81 assim, literalmente, Lindacher, ob. cit., pg. 302(2)

82 veja Lindacher, ob. cit., pg. 302(1)

83 assim narra Lindacher, ob. cit., pg. 302(1)

84 veja-se detalhes da divisão da doutrina alemã em Lindacher, ob. cit., pg. 302(1)

85 veja conclusões de Lindacher, ob. cit., pg. 302(1), o qual pessoalmente discorda do método usado pelo Tribunal alemão, demonstrando que o assunto está realmente longe de receber uma resposta absoluta, infelizmente o relato do professor alemão não esclarece o conteúdo das cláusulas consideradas abusivas.

86 veja o excelente trabalho da Procuradora do Estado do RS, Fillipi, Rejane Brasil, no sentido de defender a inexistência de tal superioridade e a equivalência entre a lei interna e o tratado recebido em nosso ordenamento, tudo com base no acórdão do S.T.F. no R.E. 80.009, ob. cit., págs. 226 ss.

87 veja os comentários de Mota, Octanny, in: "Dolo...", pg. 47 e Mattos, J.D., "O Desastre Aéreo de Abidjan...", ob. cit., pg. 170

88 veja-se Cannizzaro, discutindo as idéias de Camarda, ob. cit., pg. 296 e ss

89 veja os ensinamentos de Clavero, B. Codificacion y Constitucion: Paradigmas de un Binomio in: Quaderni Fiorentini, vol. 18 (1989), pg. 79-145 e Hesse, K. A Forfa Normativa da Constituifão, trad. Gilmar Ferreira Mendes, Porto Alegre: Sérgio Fabris, 1991

90 veja tb. Raizer, Ludwig, O Futuro do Direito Privado, in: Rev. da procuradoria Geral do Estado/RS, 9 (25), 1979, p. 11-30, Lobo, P.L. Neto Do Contrato no Estado Social, Maceió: EDUFAL, 1983, Sacco, R. Codificare: modo superato di legiferare?, in: Riv. di Dirritto Civile, 1983,125

91 veja a obra clássica de Hesse, já citada e sobre a "interpretação conforme com a Constituição" e seu desenvolvimento pela Corte Constitucional alemã, veja do mesmo autor, Grundzüge des Verfassengsrecbts der Bun. desrepublick Deutschland, Karslrube: C.F. Müller, 1967, pg. 32 e ss

92 esta é a opinião de Galgano para o caso de conflito entre as normas da Diretiva européia sobre responsabilidade por fato do produto $e$ as normas internas italianas, opinião citada por Busnelli, F. e Ponzanelli, G., La Responsabilitá del Produttore tra Legge Speciale e 
Codice Civile, in: Il Danno da Prodotti, Coord. Salvatore Patti, Pádua: Cedam, 1990, pg. 25

${ }^{93}$ reservamos o estudo mais detalhado das funções da reparação dos danos para o ponto reservado ao estudo da extensão da responsabilidade (2.c)

94 Sobre as ações coletivas no CDC, veja interessante abordagem de Tescheiner, José Maria Rosa, A̧̋̃os coletivas pró-consumidor, in: Revista da AJURIS, n. 54, p8 75 a 106

95 a origem, em última análise, do dever do fornecedor não é o direito subjetivo do consumidor, mas a lei imperativa. É uma obrigação imposta pelo poder público à um ou mais agente econômico. Sobre a possibilidade de a posteriori o consumidor ou as instituições legitimadas em caso de açōes coletivas transigirem quanto ao montante a ser pago (quantum da reparação), veja com opinião afirmativa, Nascimento, Tupinambá Miguel Castro do, Responsabilidade Civil no Código do Consumidor, Rio de Janeiro: Aide, 1991, pg. 57

96 Larenz, K. Lebrbuch des Schuldrechts, I. Bd., AT, $14^{2}$ Ed., Munique: Beck, 1987, pg. 23 e 24 (§ 2, IV)

97 sobre a natureza e as características da responsabilidade "não-culposa", veja o nosso artigo $A$ Responsabilidade do importador pelo fato do produto segundo o Código de Defesa do Consumidor, in: $\mathrm{R}$. Inf. legisl. Brasilia, $\mathrm{n}$. 111 , jul./set. 1991, pgs. 277-294

98 segundo posicão que defendi no artigo "Responsabilidade do importador", supra citado, não se trata de rilicade do posicho moldes tradicion mas responsabilidade ob, nos moldes tradicio objetiva pelo risco da aivide objetiva, por previsão legal, nos moldes da propéia, se bem que modificada.

${ }^{99}$ assim as conclusōes do Primer Congresso internacional de Daños, Buenos Aires, 1990, transcritas na obra coletiva Mosset Iturraspe, e outros, Daños, Ed, Depalma, Buenos Aires, 1991, assim tb. concorda Alpa, Guido, Diritto privato dei consumi, Bolonha: Il Molino, pg. 286 sobre a divisão dos riscos e custos e Benjamin, Antônio H., Comentários ao Código de Proteção do Consumidor, Coord. Juarez Oliveira, São Paulo: Saraiva, 1991, pg. $45 \mathrm{ss}$

100 veja, por todos, Benjamin, Antônio Herman, Comentários ao Código de Protesão do Consumidor, Saraiva, Coord. Juarez de Oliveira, São Paulo, 1991

101 sobre a socialização do dever de indenizar e os seguros, veja a obra de Leite de Campos, Diogo José, "Seguro da Responsabilidade Civil fundada em acidentes de viação", Coimbra: Almedina, 1971

102 assim França Limogi, Reparasãa do dano moral, in: RT 631, p. 29

103 muitos danos patrimoniais são designados equivocamente pela jurisprudência como danos "morais" ou extrapatrimoniais, conforme alerta Porto, Mário Moaextrapatrimoniais, conf
cir, in: RT $590, \mathrm{pg} .37$

104 assim ensinam Mazeau, H. e L., Tunc, A., Tratado Teórico y Prático de la Responsabilidade Civil Delictual y Contratual, t. I, vol. 1, pg. 424

158
105 assim o relator Des. Ruy Rosado de Aguiar Júnior, in: Rev. de Jurisprudência do Tribunal de Justiça do Rio Grande do Sul, n. 129. pg. 335

106 sobre o tema, que desperta grande interesse atualmente na Europa veja o resumo da Tese de Livre Docencia em Tübingen de Kern, Bernd-Rüdier, Die Genugturngsuntion des Schmerzenseldes - ein ponales eth ment in Schadensrecht ? in: Archiv fuir die civilistische Praxis, 191. junho 1991, pg. 247 a 272. O autor faz questão de separar a função satisfativa da funça punitiva, tão combatida no direito privado, relembre-se aqui o veto a art. 16 do CDC, o qual introduzia mult civil, isto $e$ os punnitives damnages da common

07 sobre a transacionabilidade do quantitativo a indenizar, veja Nascimento, Tupinambá Miguel Castro do Responsabilidade Civil no Código do Consumidor, Aid Editora, Rio de Janeiro, 199

108 Tenório, O. Lei de Introdusão ao Código Civil Brasi leiro, Rio de Janeiro: Borsói, 1955, pg. 64

109 sobre a tendência de introduzir cada vez mais no ordenamento jurídico de países de influencia continenal européa normas abertas ou clausulas gerais para Failitar esta evoluca a na interpretacão o cham "Direito dos Juizes', veja Scarpelli, Uberto, Dalla la

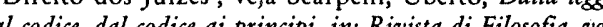

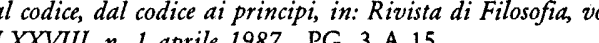

10 assim concorda Ripert, Georges, Les forces créatrices $d u$ droit, Paris: L.G.D.J., 1955, pg. 21, referindo-se ao Code Civil francês de 1804 e sua interpretação "social" assegurada pela jurisprudência

\section{Algumas considerações sobre os sistemas tributários dos estados federativos em desenvolvimento}

\section{Rômulo Maya}

Professor da Faculdade de Direito da UFRGS

\section{Resumo}

No artigo procura-se evidenciar a vinculação dos sistemas tributários dos países federativos a dois fatores, um de caráter politico e outro de natureza econômica.

O caráter político expressa-se no "princípio da coerência", distribuişão da competência tributária segundo as atribuiçóes constitucionais de cada entidade e o caráter econômico manifesta-se pelo "princípio da suficiência", isto é, a receita alocada deve cobrir o custo dos serviços a cargo da unidade federada.

Em relą̧ão ao aspecto econômico, tomando como base o trabalho de W.W.ROSTOV, tenta-se relacionar a composição do sistema tributário às etapas propostas por aquele Autor no seu livro "Etapas do Desenvolvimento Econômico".

Admitida a demonstração da tese, chega-se à conclusão final de ser o sistema tributário do país em desenvolvimento uma verdadeira variá vel, condicionada não somente aos objetivos visados, mas também à escolha das matérias im poníveis.

Com a proximidade da revisão constitucional a ser realizada a partir de outubro do corrente ano, inclusive com perspectiva de reformulação quase total do "Sistema Tributário Nacional" previsto nos artigos 145 a 162 do Capítulo I do Título VI da nossa Carta Magna, parece-nos apropriado tecer algumas considerações sobre a matéria, oferecendo-as à apreciação dos interessados, nos termos que seguem.

O sistema tributário pode ser definido como sendo o conjunto dos tributos exigí- veis no país e das normas jurídicas que disciplinam o exercício do poder impositivo pelas entidades políticas nacionais. Assim entendido, nos estados federativos o sistema tributário está vinculado a dois fatores fundamentais, um político e outro econômico.

As federações, onde co-existem duas ou mais espécies de entidades entre as quais se reparte o exercício do poder impositivo, têm seus sistemas tributários condicionados, como julgamos evidente, às atribuições constitucionais dos entes políticos integrantes do estado. A distribuição das rendas tributárias deve ser realizada tendo em vista, exatamente, as diferentes responsabilidades a eles outorgadas pela Lei Maior. Assim, por exemplo, se à União Federal couber dirigir e legislar sobre o comércio exterior, ser-lhe-ão, necessariamente, entregues os impostos de importação e exportação.

Por outro lado, faz-se mistér que os sistemas tributários assegurem a essas entidades as receitas necessárias e suficientes para o perfeito desempenho de suas funções públicas. De modo que, sob o ponto de vista econômico, aos sistemas tributários das nações federadas, cabe obedecer este parâmetro, devendo ser capazes de proporcionar a todos os entes adminitrativos autônomos os recuros indispensáveis à realização dos seus fins, efetivando, ao mesmo tempo, a repartição da renda tributária nacional de conformidade com as atribuições constitucionais deferidas a cada um deles. Qualquer outra modalidade de divisão da receita tributária, que desconheça estes princípios báR. Fac. Direito UFRGS, Porto Alegre, 9(1): 159-162, nov. 1993 